\title{
Evaluation of tropospheric $\mathrm{SO}_{2}$ retrieved from MAX-DOAS measurements in Xianghe, China
}

\author{
T. Wang ${ }^{1,2}$, F. Hendrick ${ }^{2}$, P. Wang ${ }^{1}$, G. Tang ${ }^{1}$, K. Clémer ${ }^{2,}$, H. Yu ${ }^{2}$, C. Fayt ${ }^{2}$, C. Hermans ${ }^{2}$, C. Gielen ${ }^{2}$, J.-F. Müller ${ }^{2}$, \\ G. Pinardi $^{2}$, N. Theys ${ }^{2}$, H. Brenot ${ }^{2}$, and M. Van Roozendael ${ }^{2}$ \\ ${ }^{1}$ Institute of Atmospheric Physics, Chinese Academy of Sciences, Beijing, China \\ ${ }^{2}$ Belgian Institute for Space Aeronomy, Brussels, Belgium \\ *now at: Instituut voor Sterrenkunde, Katholieke Universiteit Leuven, Leuven, Belgium
}

Correspondence to: F. Hendrick (franch@oma.be)

Received: 7 January 2014 - Published in Atmos. Chem. Phys. Discuss.: 11 March 2014

Revised: 15 September 2014 - Accepted: 15 September 2014 - Published: 23 October 2014

\begin{abstract}
Ground-based multi-axis differential optical absorption spectroscopy (MAX-DOAS) measurements of sulfur dioxide $\left(\mathrm{SO}_{2}\right)$ have been performed at the Xianghe station $\left(39.8^{\circ} \mathrm{N}, 117.0^{\circ} \mathrm{E}\right)$ located at $\sim 50 \mathrm{~km}$ southeast of Beijing from March 2010 to February 2013. Tropospheric $\mathrm{SO}_{2}$ vertical profiles and corresponding vertical column densities (VCDs), retrieved by applying the optimal estimation method to the MAX-DOAS observations, have been used to study the seasonal and diurnal cycles of $\mathrm{SO}_{2}$, in combination with correlative measurements from in situ instruments, as well as meteorological data. A marked seasonality was observed in both $\mathrm{SO}_{2} \mathrm{VCD}$ and surface concentration, with a maximum in winter (February) and a minimum in summer (July). This can be explained by the larger emissions in winter due to the domestic heating and, in case of surface concentration, by more favorable meteorological conditions for the accumulation of $\mathrm{SO}_{2}$ close to the ground during this period. Wind speed and direction are also found to be two key factors in controlling the level of the $\mathrm{SO}_{2}$ related pollution at Xianghe. In the case of east or southwest wind, the $\mathrm{SO}_{2}$ concentration does not change significantly with the wind speed, since the city of Tangshan and heavy polluting industries are located to the east and southwest of the station, respectively. In contrast, when wind comes from other directions, the stronger the wind, the less $\mathrm{SO}_{2}$ is observed due to a more effective dispersion. Regarding the diurnal cycle, the $\mathrm{SO}_{2}$ amount is larger in the early morning and late evening and lower at noon, in line with the diurnal variation of pollutant emissions and atmospheric stability. A strong correlation with correlation coefficients between
\end{abstract}

0.6 and 0.9 is also found between $\mathrm{SO}_{2}$ and aerosols in winter, suggesting that anthropogenic $\mathrm{SO}_{2}$, through the formation of sulfate aerosols, contributes significantly to the total aerosol content during this season. The observed diurnal cycles of MAX-DOAS $\mathrm{SO}_{2}$ surface concentration are also in very good agreement (correlation coefficient close to 0.9 ) with those from collocated in situ data, indicating the good reliability and robustness of our retrieval.

\section{Introduction}

Sulfur dioxide $\left(\mathrm{SO}_{2}\right)$, one of the most common air pollutants, is of major concern in pollution control acts (Gauderman et al., 2000). In China, the Ministry of Environmental Protection (MEP) lists $\mathrm{SO}_{2}$ as one of the three conventional pollutants, together with $\mathrm{NO}_{2}$ and $\mathrm{PM}_{10}$, and daily averaged $\mathrm{SO}_{2}$ concentrations were used as an indicator to quantify the level of pollution (Yan et al., 2010). This trace gas is predominantly produced by the burning of fossil fuels including oil and coal, and the smelting of mineral ores that contain sulfur (Yan et al., 2005; Zhao et al., 2012). $\mathrm{SO}_{2}$ contributes to a large extent to the process of acidification resulting in acid rain and to the formation of sulfate aerosols, both of which cause human health damages, building surface corrosion, and visibility reduction. In particular, the secondary pollutant sulfate aerosols generated by $\mathrm{SO}_{2}$ are the primary source of fine solid particles in cities, which are also responsible for severe air pollution issues (Meng et al., 2009). In addition, the ongoing industrial development, population growth, and heavy 
traffic contribute to higher energy consumption and, therefore, to an increase in $\mathrm{SO}_{2}$ emissions into the atmosphere (Wu et al., 2013). Consequently, in order to meet the urgent demand to improve and control air quality in China, as well as to promote sustainable development, it is of the greatest importance to study the evolution of a pollutant like $\mathrm{SO}_{2}$ and to identify its possible origins.

So far, the $\mathrm{SO}_{2}$ surface concentration has been monitored using in situ and long-path DOAS (differential optical absorption spectroscopy) instruments (Meng et al., 2009), while satellite sensors like GOME, SCIAMACHY, GOME2, OMI, OMPS, and IASI have shown their ability to measure the $\mathrm{SO}_{2}$ vertical column density (VCD) over polluted areas (see, e.g., Eisinger and Burrows, 1998; Krotkov et al., 2006; Lee et al., 2009; Nowlan et al., 2011; Fioletov et al., 2013; Yang et al., 2013; Boynard et al., 2014). During the last decade, a new remote sensing technique called MAX-DOAS (multi-axis differential optical absorption spectroscopy) has been developed, providing information on both VCD and vertical distribution of trace gases in the troposphere (Hönninger et al., 2004; Platt and Stutz, 2008). It is based on the measurement of sunlight scattered at multiple elevation angles towards the horizon, thus increasing the sensitivity to absorbers present close to the ground compared to the zenith viewing geometry (Hönninger et al., 2004). MAX-DOAS studies published so far have been mainly focused on the retrieval of $\mathrm{NO}_{2}$ (e.g., Wittrock et al., 2004; Vlemmix et al., 2010; Frins et al., 2012; Hendrick et al., 2014; Ma et al., 2013; Wang et al., 2014), halogen oxides like BrO and IO (e.g., Frieß et al., 2011; Großmann et al., 2013), formaldehyde (e.g., Heckel et al., 2005; Wagner et al., 2011), and aerosols (e.g., Wagner et al., 2004; Frieß et al., 2006; Clémer et al., 2010). A lot of work has been done on MAX-DOAS measurements of volcanic $\mathrm{SO}_{2}$ (e.g., Bobrowski et al., 2007; Galle et al., 2010), but so far only a few studies deal with MAX-DOAS observations of this species in polluted areas (e.g., Irie et al., 2011; Lee et al., 2008; Wu et al., 2013), despite the fact that, as for other trace gases like $\mathrm{NO}_{2}, \mathrm{HCHO}$, and $\mathrm{BrO}$, the combination of both surface concentration and VCD retrievals makes MAX-DOAS a useful technique for validating $\mathrm{SO}_{2}$ satellite data.

Here we present 3 years (March 2010-February 2013) of continuous MAX-DOAS $\mathrm{SO}_{2}$ observations at the $\mathrm{Xi}$ anghe Observatory, China $\left(39.8^{\circ} \mathrm{N}, 117.0^{\circ} \mathrm{E}\right)$, located at about $50 \mathrm{~km}$ southeast of Beijing, at the borders among Beijing, Tangshan and Tianjin (see Fig. 1). The station is operated by the Institute of Atmospheric Physics (IAP)/Chinese Academy of Sciences (CAS) while the MAX-DOAS instrument was developed by the Belgian Institute for Space Aeronomy (BIRA-IASB) and validated in several intercomparison exercises, in particular as part of the international Cabauw Intercomparison of Nitrogen Dioxide measuring Instruments (CINDI, Roscoe et al., 2010) and more recently a national Chinese MAX-DOAS instrument intercomparison campaign held in Xianghe (Wang et al., 2013). $\mathrm{SO}_{2}$ MAX-

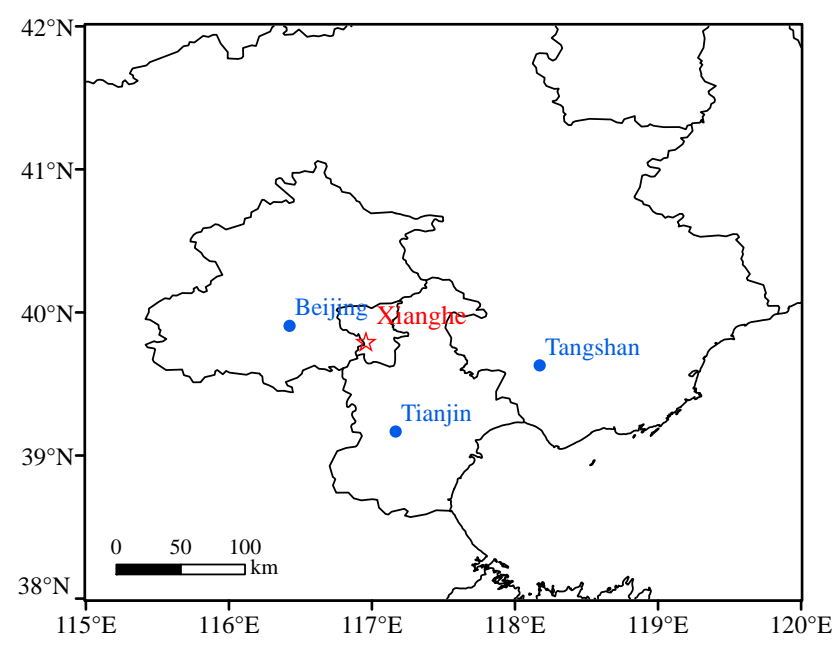

Figure 1. Location of the Xianghe Observatory (red star) and major neighborhood cities.

DOAS observations are used here in combination with in situ measurements as well as conventional meteorological data (temperature, humidity, wind direction and speed) to investigate the seasonal and diurnal cycles of $\mathrm{SO}_{2}$ vertical profiles and VCDs. The paper is divided into three main sections. In Sect. 2, the $\mathrm{SO}_{2}$ measurements are described, including the DOAS analysis, vertical profile retrieval, and retrieval verification through comparison with in situ data. The seasonal and diurnal cycles of $\mathrm{SO}_{2}$, and the relationship between $\mathrm{SO}_{2}$ and aerosols are investigated in Sect. 3. Finally, conclusions are given Sect. 4 .

\section{Data}

\subsection{Instrument}

The MAX-DOAS instrument operated at the Xianghe Observatory consists of three components: a thermo-regulated box containing two spectrometers, an optical head mounted on a sun tracker, and two computers for instrument control and data storage (Clémer et al., 2010). The optical head and the two spectrometers are linked by two-way splitter optical fibers (Clémer et al., 2010; Wang et al., 2013). This setup is capable of measuring scattered as well as direct sunlight. One spectrometer works in the UV region (300 to $390 \mathrm{~nm}$ ) and its instrumental function is close to a Gaussian with a full width at half maximum (FWHM) of $0.4 \mathrm{~nm}$. The other spectrometer covers the visible wavelength range from 400 to $720 \mathrm{~nm}$ with a FWHM equal to $0.9 \mathrm{~nm}$. During the observation, the azimuth direction of the telescope is fixed to the north. A full MAX-DOAS scan consists of nine elevation viewing angles $\left(2,4,6,8,10,12,15,30\right.$, and $\left.90^{\circ}\right)$ and lasts about $15 \mathrm{~min}$ (Clémer et al., 2010). The 3-year data set investigated in this study covers the March 2010 to February 2013 period. 
Table 1. Settings used for the $\mathrm{SO}_{2}$ and $\mathrm{O}_{4}$ DOAS analysis.

\begin{tabular}{llll}
\hline Parameter & Data source & \multicolumn{2}{c}{ Fitting interval nm } \\
& & $338-370 \mathrm{~nm}\left(\mathrm{O}_{4}\right)$ & $305-317.5 \mathrm{~nm}\left(\mathrm{SO}_{2}\right)$ \\
\hline $\mathrm{NO}_{2}$ & Vandaele et al. (1998) $220 \mathrm{~K}, 294 \mathrm{~K}$ & $\mathrm{x}$ & $\mathrm{x}($ only 294 K) \\
$\mathrm{SO}_{2}$ & Vandaele et al. (1994) $294 \mathrm{~K}$ & $\mathrm{x}$ \\
$\mathrm{O}_{3}$ & Bogumil et al. (2003) $223 \mathrm{~K}, 243 \mathrm{~K}$ & $\mathrm{x}($ only $223 \mathrm{~K})$ & $\mathrm{x}$ \\
$\mathrm{O}_{4}$ & Hermans et al. (2003) $296 \mathrm{~K}$ & $\mathrm{x}$ & \\
$\mathrm{BrO}$ & Fleischmann et al. (2004) $223 \mathrm{~K}$ & $\mathrm{x}$ & \\
$\mathrm{H}_{2} \mathrm{CO}$ & Meller and Moortgat (2000) $293 \mathrm{~K}$ & $\mathrm{x}$ & $\mathrm{x}$ \\
$\mathrm{Ring}$ & Chance and Spurr (1997) & $\mathrm{x}$ & 5 \\
Polynomial degree & & 5 & 5 \\
\hline
\end{tabular}

\subsection{DOAS analysis}

Scattered-sunlight spectra measured at different elevation angles (EVAs) are analyzed using the DOAS technique (Platt and Stutz, 2008) where high-frequency molecular absorption structures in the UV and visible regions of the spectrum are exploited to detect and quantify a number of key atmospheric gases such as $\mathrm{SO}_{2}$.

In this work, the spectra obtained from MAX-DOAS observations are analyzed using the QDOAS spectralfitting software suite developed at BIRA-IASB (http://uv-vis. aeronomie.be/software/QDOAS/). QDOAS calculates the $\mathrm{SO}_{2}$ differential slant column densities (DSCDs), which are defined as the difference between the trace-gas concentration integrated along the effective light path and the amount of the absorber in a measured reference spectrum. (MAX-)DOAS is recognized as a "self-calibrating" technique because differential absorptions are measured and therefore the impact of possible instrumental degradations can be largely removed by using appropriate reference spectra. In contrast, in situ instruments need to be optically and/or chemically calibrated on a regular basis, especially when performing long-term measurements. For tropospheric studies, a zenith spectrum is frequently chosen as reference, in this way also removing the contribution of the stratosphere in off-axis DSCDs.

The $\mathrm{SO}_{2}$ DOAS settings have been investigated through sensitivity tests on several key parameters, such as wavelength interval, choice of absorption cross sections, polynomial order, and intensity off-set terms. The selected settings are summarized in Table 1 and described in the next section.

$\mathrm{SO}_{2}$ fitting windows ranging between 303 and $325 \mathrm{~nm}$ have generally been used in previous studies (Bobrowski and Platt, 2007; Lee et al., 2008; Galle et al., 2010; Irie et al., 2011). At wavelengths shorter than $303 \mathrm{~nm}$, the limiting factor is the strong ozone absorption which interferes with $\mathrm{SO}_{2}$, leading to lower signal to noise ratio. At wavelengths longer than $325 \mathrm{~nm}$, the $\mathrm{SO}_{2}$ differential absorption signal becomes too weak. In order to identify the wavelength interval which minimizes both random and systematic uncertainties on $\mathrm{SO}_{2}$ retrieval, six wavelength intervals have been investigated. The results of these sensitivity tests for 2 ex- ample days are presented in Figs. 2 and 3. On the first day (1 October 2011), the $\mathrm{SO}_{2}$ content is minimum and stable in time. On the second day (4 October 2011), large variations of the $\mathrm{SO}_{2}$ content occur, so the ability of the different intervals to give consistent and stable values can be verified. As can be seen, the $305-317.5 \mathrm{~nm}$ interval provides the lowest fitting errors throughout the day and the smallest dependence on the solar zenith angle (SZA) for both days. Due to the larger absorption and therefore interference by $\mathrm{O}_{3}$ at large SZAs, it has been decided to exclude measurements taken at SZAs larger than $75^{\circ}$. For these tests, the following spectral signatures have been included: $\mathrm{SO}_{2}, \mathrm{O}_{3}, \mathrm{NO}_{2}$, and the Ring effect (Grainger and Ring, 1962; Chance and Spurr, 1997). Daily zenith-sky radiance spectra recorded around local noon have been selected as reference. To account for the temperature dependence of the ozone absorption, cross sections at two different temperatures (223 and $243 \mathrm{~K}$ ) were used according to Van Roozendael et al. (2006). A fifth-order polynomial is applied to fit the low-frequency spectral structure due to Rayleigh and Mie scattering and instrumental effects. Attempts to further adjust these settings, e.g., by adding $\mathrm{BrO}$ cross section or by including additional ozone correction terms according to Puksite et al. (2010), were not successful (less stable retrievals with larger noise on the $\mathrm{SO}_{2}$ DSCDs).

Figure 4 shows a typical example of a DOAS fit for $\mathrm{SO}_{2}$ at $43^{\circ} \mathrm{SZA}$. We see that fitting residuals range in between $-2 \times 10^{-3}$ and $2 \times 10^{-3}$, corresponding to a root mean square (rms) of $9 \times 10^{-4}$, which appears to be small in comparison to the $\mathrm{SO}_{2}$ differential structures presented in the lowest panel of the figure. The typical fitting uncertainty in $\mathrm{SO}_{2}$ DSCDs is of about $1-6 \times 10^{15}$ molec $\mathrm{cm}^{-2}$ (less than $10 \%$ ) and, for the case illustrated here, corresponds to $2 \%$. For near-noon conditions, the detection limit on the $\mathrm{SO}_{2}$ DSCD can be conservatively estimated as 3 times the $1 \sigma$ uncertainty in the slant column, which means approximately $3 \times 10^{15}$ molec $\mathrm{cm}^{-2}$. This detection limit is similar for the vertical columns estimated using the geometrical approximation at $30^{\circ}$ elevation (see Sect. 2.3). Vertical columns derived from the full inversion generally have a smaller detection limit, owing to the gain in sensitivity obtained when including near horizontal viewing measurements. 

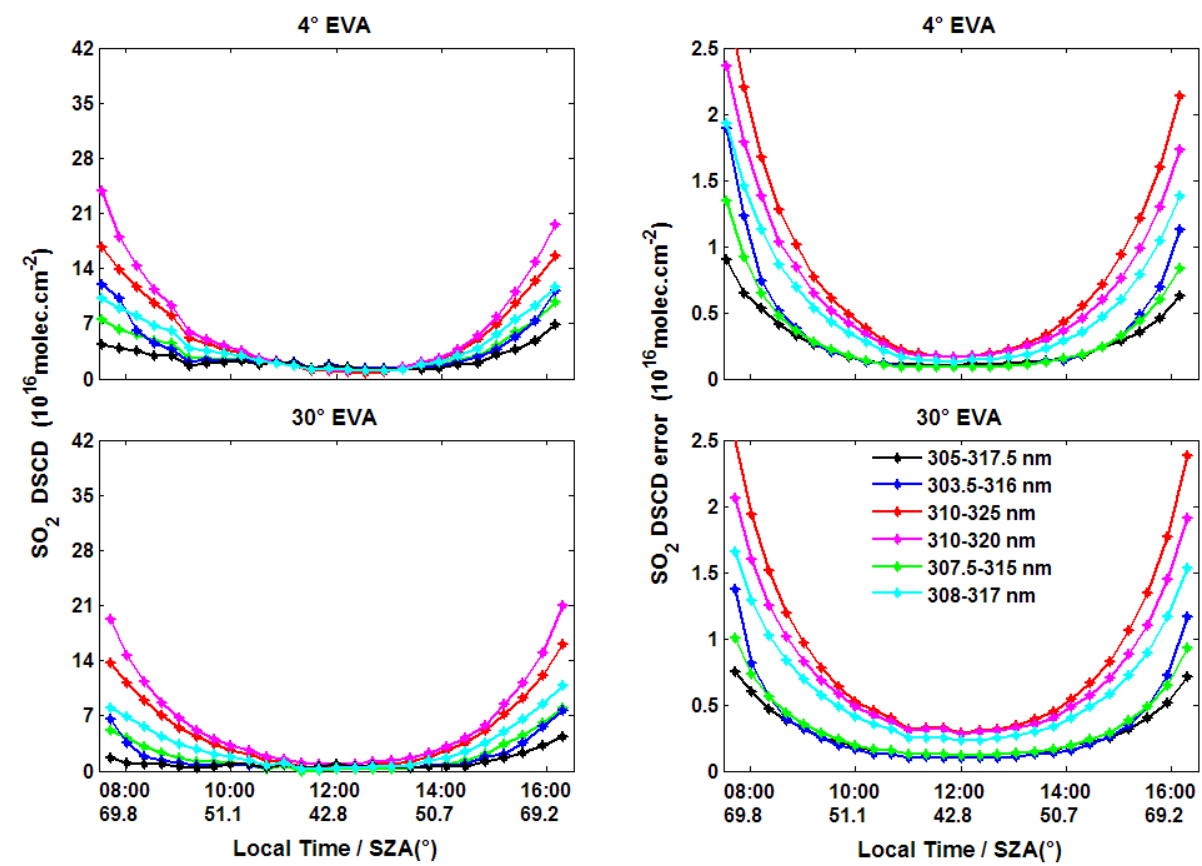

Figure 2. $\mathrm{SO}_{2}$ DSCDs (first column) and corresponding fitting uncertainties (second column) retrieved at $4^{\circ}$ (upper plots), $30^{\circ}$ (lower plots) elevation (EVA) for different wavelength intervals on 1 October 2011. Local time (h) and corresponding SZA $\left({ }^{\circ}\right)$ are given on the $x$ axis.
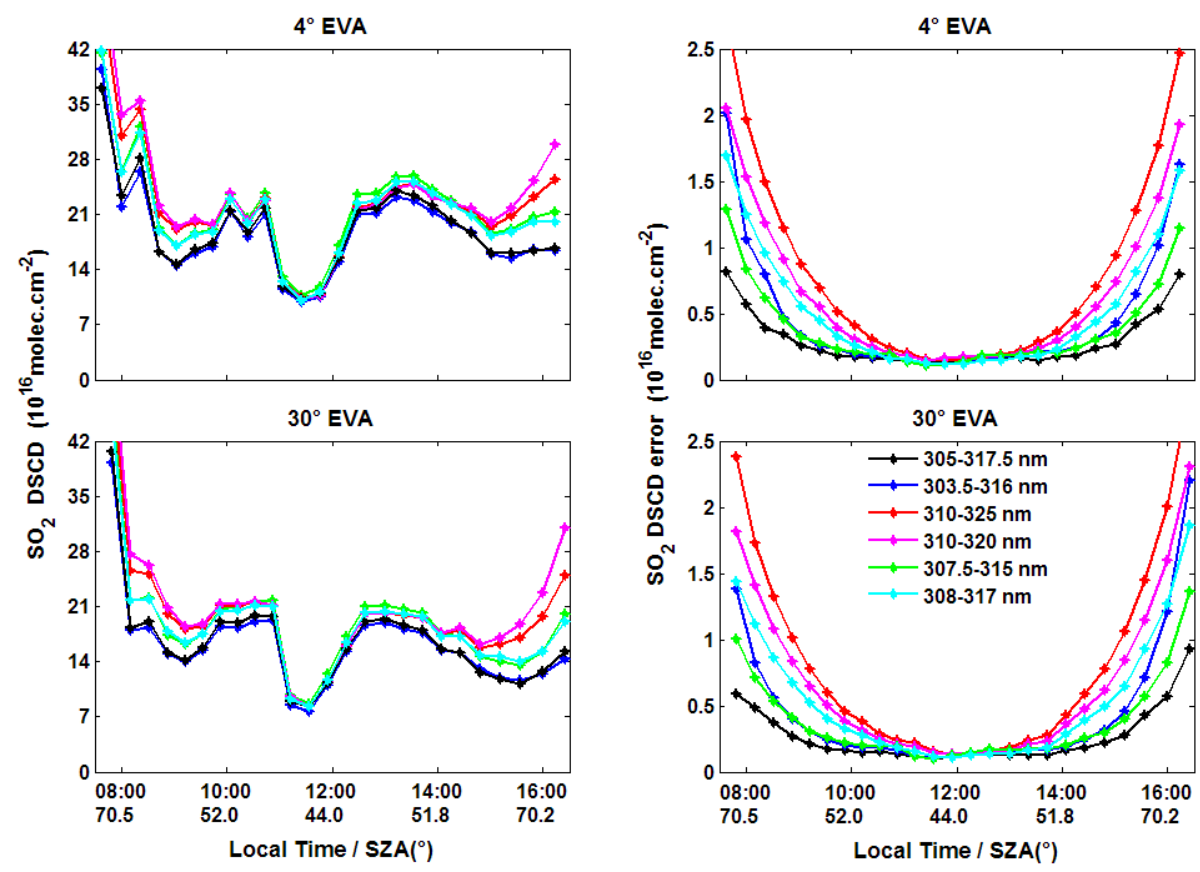

Figure 3. Same as Fig. 2, but for 4 October 2011.

\subsection{Profile retrieval}

$\mathrm{SO}_{2}$ vertical profiles are retrieved for each MAX-DOAS scan by using the bePRO profiling tool developed at BIRA-IASB (Clémer et al., 2010; see also Hendrick et al., 2014). It is based on the optimal estimation method (Rodgers, 2000) and

includes the LIDORT radiative transfer model (RTM) as a forward model. A two-step approach is implemented in bePRO: first, aerosol extinction profiles are retrieved from measured $\mathrm{O}_{4}$ DSCDs. This step is needed because the aerosols strongly influence the effective light path in the atmosphere and therefore the optical density of trace gases like $\mathrm{SO}_{2}$. 


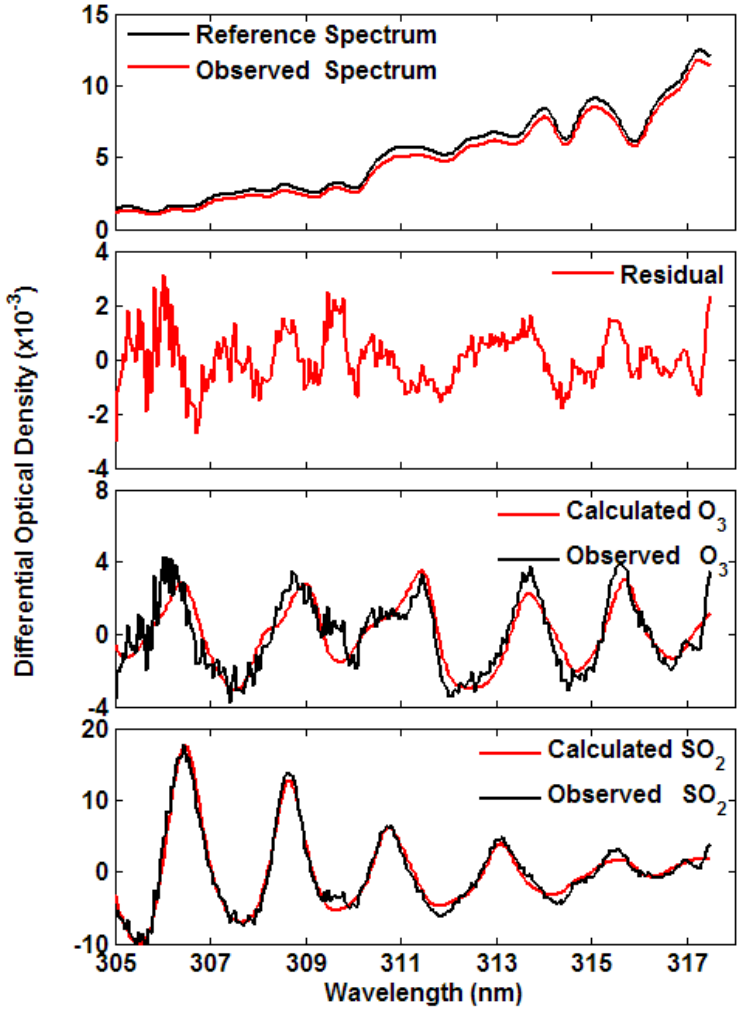

Figure 4. Example of DOAS fit result for $\mathrm{SO}_{2}$. It corresponds to 29 September 2010 at $\sim$ 11:20 LT. SZA and EVA values are 43 and $30^{\circ}$, respectively.

Secondly, bePRO is applied to measured trace-gas DSCDs using the retrieved aerosol extinction profiles for the radiative transfer calculations (see below). Since the DOAS analysis is performed using daily zenith radiance spectra around noon as reference, bePRO is fed for each scan with $\mathrm{SO}_{2}$ and $\mathrm{O}_{4}$ DSCDs obtained by taking the difference between offaxis DSCDs and the zenith DSCD interpolated at the time of each off-axis measurement using the zenith DSCDs of two consecutive scans. Proceeding this way allows properly removing the contributions of the stratosphere from the measurements and is similar, at least for SZA $<75^{\circ}$, to taking the zenith spectrum of each scan as reference for the DOAS analysis.

Both linear and nonlinear iterative approaches have been implemented in our profiling algorithm. For weak absorbers like $\mathrm{NO}_{2}, \mathrm{HCHO}$ and $\mathrm{SO}_{2}$, the linear method is selected (see, e.g., Hendrick et al., 2004). In case of strong absorbers like $\mathrm{O}_{4}$, the nonlinear iterative approach is used:

$$
\begin{aligned}
& \boldsymbol{x}_{i+1}=\boldsymbol{x}_{i}+\left(\mathbf{S}_{\mathrm{a}}^{-1}+\mathbf{K}_{i}^{T} \mathbf{S}_{\varepsilon}^{-1} \mathbf{K}_{i}\right)^{-1} \cdot\left[\mathbf{K}_{i}^{T} \mathbf{S}_{\varepsilon}^{-1}\left(\boldsymbol{y}-F\left(\boldsymbol{x}_{i}\right)\right)\right. \\
& \left.\quad-\mathbf{S}_{\mathrm{a}}^{-1}\left(\boldsymbol{x}_{i}-\boldsymbol{x}_{\mathrm{a}}\right)\right],
\end{aligned}
$$

where $\boldsymbol{y}$ is the observation vector with the DSCDs at the different EVAs, $F$ is the forward model describing the physics of the measurements, $\mathbf{K}$ is the weighting function, expressing the sensitivity of the measurements to changes in the aerosol extinction or $\mathrm{SO}_{2}$ vertical profile and calculated online by the LIDORT RTM, $\mathbf{S}_{\varepsilon}$ is the measurement uncertainty covariance matrix, $\boldsymbol{x}_{\mathrm{a}}$ and $\mathbf{S}_{\mathrm{a}}$ are the a priori vertical profile and its corresponding error covariance matrix. A priori information is needed in the OEM method in order to indirectly reject unrealistic solutions compatible with the measurements. Another important quantity in the OEM is the averaging kernel matrix $\mathbf{A}$, which represents the sensitivity of the retrieval to the true state. More specifically, each element $\mathbf{A}_{\mathrm{ij}}$ in the matrix A describes the sensitivity of the retrieval at $i$ th level to the true states at the different altitude levels $j$. Furthermore, the trace of the matrix A gives the degrees of freedom of signal (DFS), which corresponds to the number of independent pieces of information contained in the measurements. Due to the nonlinearity of the inverse problem in case of aerosols, the solution to Eq. (1) must be iterated until satisfactory convergence is achieved between measured DSCDs and those calculated using the retrieved aerosol extinction vertical profile.

Regarding the choice of the a priori profile $\boldsymbol{x}_{\mathrm{a}}$, exponentially decreasing a priori $\mathrm{SO}_{2}$ and aerosol extinction profiles with a fixed scaling height of $0.5 \mathrm{~km}$ have been constructed according to the following expression:

$\boldsymbol{x}_{\mathrm{a}}(z)=\frac{\mathrm{VCD}_{\mathrm{a}}}{\mathrm{SH}} e^{-\frac{z}{\mathrm{SH}}}$,

where $\boldsymbol{x}_{\mathrm{a}}(z)$ is the a priori profile, $\mathrm{SH}$ the scaling height $(0.5 \mathrm{~km})$, and $\operatorname{VCD}_{\mathrm{a}}\left(\mathrm{AOD}_{\mathrm{a}}\right)$ is the a priori vertical column density (aerosol optical depth). For each scan, $\mathrm{VCD}_{\mathrm{a}}$ is derived using the geometrical approximation method; that is, the $\mathrm{SO}_{2}$ layer is assumed to be located below the scattering altitude at $30^{\circ} \mathrm{EVA}$, so that tropospheric $\mathrm{SO}_{2} \mathrm{VCDs}$ can be derived by applying a geometrical air mass factor (AMF) to measured $30^{\circ}$ EVA DSCDs (Hönninger et al., 2004; Brinksma et al., 2008; see also Hendrick et al., 2014). In case of aerosols, a fixed AOD of 0.2 is used. Since the DOAS fitting intervals are different for $\mathrm{SO}_{2}$ and aerosols, the aerosol extinction profiles utilized as input for the calculation of $\mathrm{SO}_{2}$ weighting functions have been derived by directly converting the aerosol profiles retrieved in the $338-370 \mathrm{~nm}$ wavelength range to the $305-317.5 \mathrm{~nm}$ interval using the Ångström exponents (Cachorro et al., 2000) retrieved from collocated CIMEL/AERONET sun photometer measurements (Holben et al., 1998; see http://aeronet.gsfc.nasa.gov):

$\operatorname{extinction}(z, 313 \mathrm{~nm})=\operatorname{extinction}(z, 360 \mathrm{~nm})$

$$
\times(313 / 360)^{-\alpha}
$$

where $z$ is the altitude and $\alpha$ is the Angström exponent.

The $340-440 \mathrm{~nm}$ exponents are used in a first approximation since values for a wavelength range closer to the $\mathrm{SO}_{2}$ fitting interval (305-317.5 $\mathrm{nm}$ ) are not available yet. The corresponding mean scaling factor for the March 2010-February 2013 period is of $1.16 \pm 0.06$. The single scattering albedo 
(a)

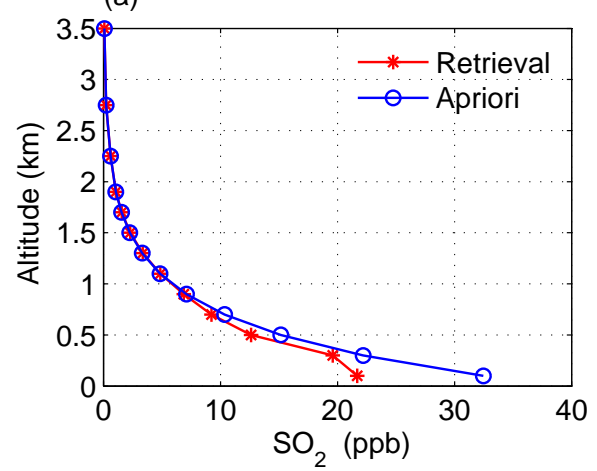

(c)

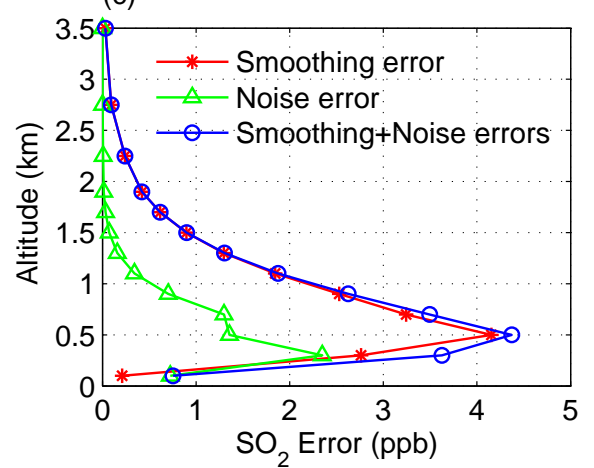

(b)

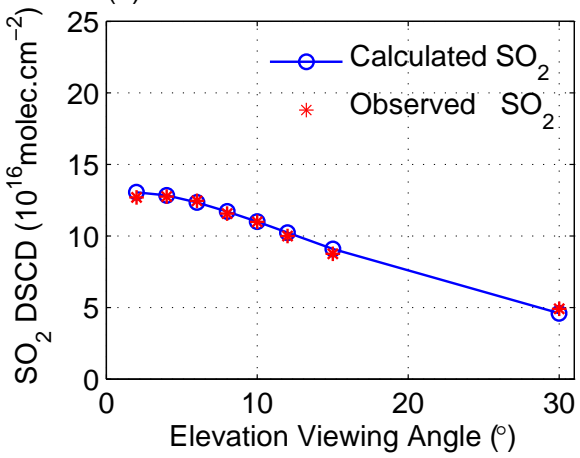

(d)

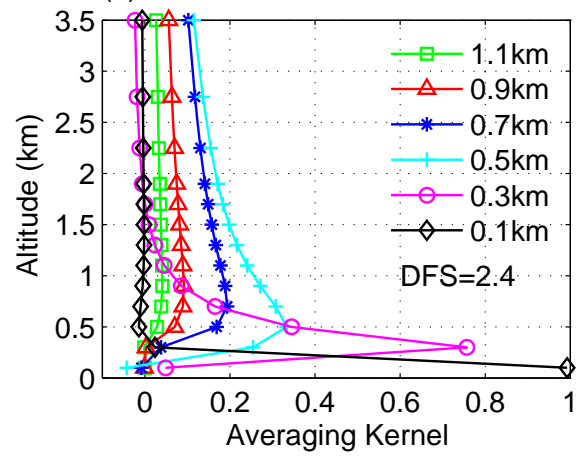

Figure 5. Example of $\mathrm{SO}_{2}$ vertical profile retrieval from MAX-DOAS measurements at Xianghe (29 September, 2010 at 10:15 LT). (a) A priori (blue) and retrieved profile (red); (b) observed (red) and calculated (blue) DSCD (c) smoothing error (red), noise error (green) and sum of these two (blue); (d) averaging kernels.

Table 2. Error budget of retrieved $\mathrm{SO}_{2}$ concentration $(0-200 \mathrm{~m})$ and VCD.

\begin{tabular}{lrr}
\hline Uncertainty (\%) & $\begin{array}{r}\text { Concentration } \\
(0-200 \mathrm{~m})\end{array}$ & VCD \\
\hline Smoothing + noise errors & 16 & 11 \\
Uncertainty related to aerosols & 16 & 5 \\
Uncertainty related to the a priori & 8 & 19 \\
Uncertainty in $\mathrm{SO}_{2}$ cross section & 5 & 5 \\
\hline Total uncertainty & 24 & 23 \\
\hline
\end{tabular}

and phase function of aerosols at $360 \mathrm{~nm}$ required by bePRO for retrieving aerosol extinction profiles are calculated offline based on the aerosol size distribution and refractive index retrieved from the same CIMEL/AERONET sun photometer measurements as above. The temperature-pressure profiles are obtained from the US standard atmosphere. $\mathbf{S}_{\varepsilon}$ and $\mathbf{S}_{\mathrm{a}}$ matrices are similar as in Clémer et al. (2010) and Hendrick et al. (2014). $\mathbf{S}_{\varepsilon}$ is a diagonal matrix, with variances equal to the square of the DOAS fitting error. For $\mathbf{S}_{\mathrm{a}}$, the diagonal element corresponding to the lowest layer, $\mathbf{S}_{\mathrm{a}}(1.1)$, is set equal to the square of a scaling factor $\beta$ times the maximum partial VCD (AOD) of the profiles. Here $\beta=0.4$ for $\mathrm{SO}_{2}$ and 0.2 for aerosol. The other diagonal elements decrease linearly with altitude down to $0.2 \times \mathbf{S}_{\mathrm{a}}(1.1)$. The off-diagonal terms in $\mathbf{S}_{\mathrm{a}}$ were set using Gaussian functions as follows:

$\mathbf{S}_{\mathrm{a}}(i, j)=\sqrt{\mathbf{S}_{\mathrm{a}}(i, i) \mathbf{S}_{\mathrm{a}}(j, j) \exp \left(-\ln (2)\left(\frac{z_{i}-z_{j}}{\gamma}\right)^{2}\right)}$,

where $z_{i}$ and $z_{j}$ are the altitudes of $i$ th and $j$ th levels, respectively. The correlation length is set to $0.1 \mathrm{~km}$ for $\mathrm{SO}_{2}$ and $0.05 \mathrm{~km}$ for aerosol in order to optimize the DFS.

The retrieval altitude grid is also the same as in Clémer et al. (2010) and Hendrick et al. (2014), i.e., 10 layers of $200 \mathrm{~m}$ thickness between 0 and $2 \mathrm{~km}, 2$ layers of $500 \mathrm{~m}$ between 2 and $3 \mathrm{~km}$ and 1 layer between 3 and $4 \mathrm{~km}$.

Figure 5 shows an example of a $\mathrm{SO}_{2}$ profile retrieval (Xianghe, 29 September 2010, 10:15 LT). Figure 5a compares the a priori and retrieved profiles; Fig. 5b shows an example of fit results, i.e., the comparison between measured DSCDs and those calculated from the retrieved profile. The quality of the profile retrieval is checked for each scan by calculating the relative root mean square error (RMSE) between observed and calculated DSCDs. This RMSE corresponds to the standard RMSE expressed in molec $\mathrm{cm}^{-2}$ divided by the mean DSCD of the scan. All retrievals based on the following selection criteria have been selected: RMSE $<15 \%$, DFS $>0.7$, and negative values not allowed. For each year, 


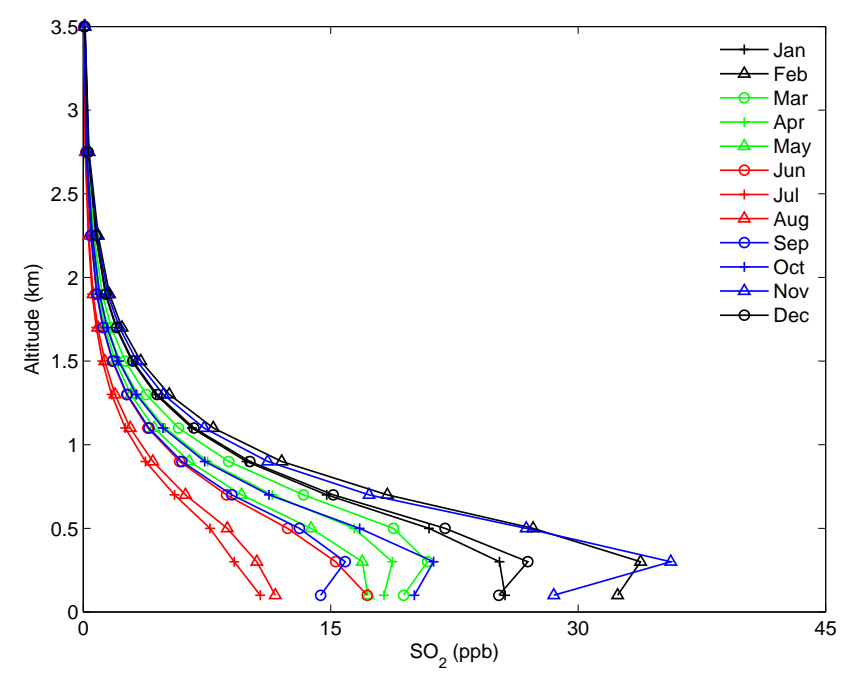

Figure 6. Monthly averaged $\mathrm{SO}_{2}$ concentration vertical profiles for the March 2010-February 2013 period.

the number of selected retrievals using these criteria reaches $\sim 70 \%$ of the total number of scans.

Also shown in Fig. 5 are the smoothing and noise errors (c) and the averaging kernels (d). Regarding the errors, the smoothing error limits the ability of the retrieval to obtain solutions far from the a priori, while the noise error is related to the propagation of the noise in the measurements into the retrieval (Rodgers, 2000). From Fig. 5c, we see that the smoothing error is significantly larger than the noise error, except in the 0-200 $\mathrm{m}$ layer. The averaging kernels show that the retrieval is mainly sensitive to the layer close to the surface in addition to the total vertical column. In this example, the DFS is about 2.4, suggesting that two independent pieces of information can be determined from the measurements.

The error budget is presented in Table 2. Uncertainty related to aerosols is estimated by retrieving $\mathrm{SO}_{2}$ profiles using wavelength-converted retrieved aerosol profiles plus their corresponding error (i.e., the sum of smoothing and noise errors plus a $20 \%$ error due to the uncertainty in the $\mathrm{O}_{4}$ cross sections; see Clémer et al., 2010) as input and comparing the results to the standard retrievals. The uncertainty in the $\mathrm{SO}_{2}$ cross sections is set to $5 \%$, as suggested by Vandaele et al. (1994). The uncertainty in the a priori profiles is estimated by taking $\mathrm{SH}=1 \mathrm{~km}$ in Eq. (2) instead of $0.5 \mathrm{~km}$ in the standard retrieval. The total uncertainty is calculated by adding the different terms in Gaussian quadrature.

Monthly-mean $\mathrm{SO}_{2}$ profiles are shown in Fig. 6. There is a maximum $\mathrm{SO}_{2}$ concentration in the $200-400 \mathrm{~m}$ layer for each profile, except in summer where the maximum is located near the surface. The largest vertical gradient is observed in February and November, the minimum in July and August. This is mainly due to the fact that the $\mathrm{SO}_{2}$ emissions are the highest in February and November. This will be discussed in detail below.

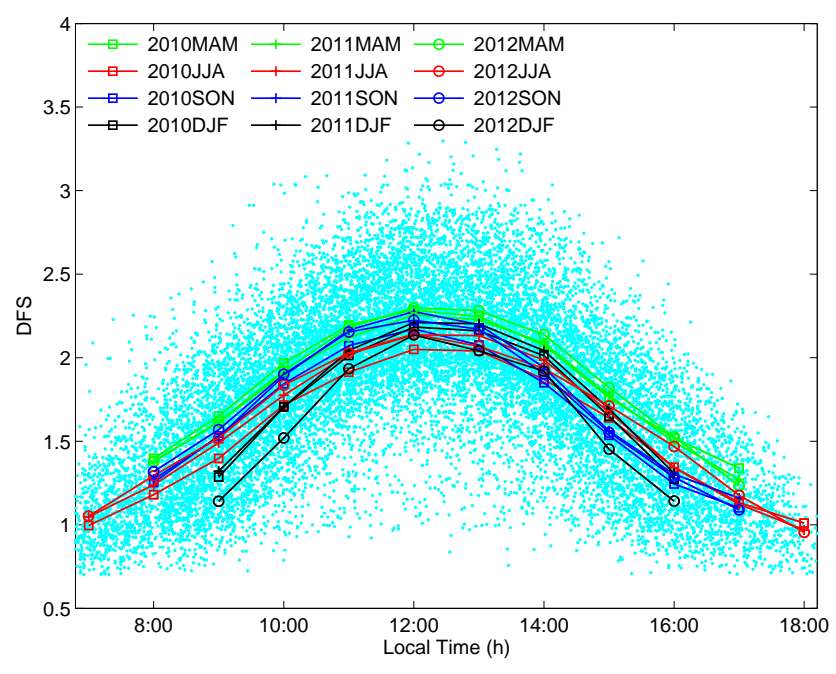

Figure 7. Seasonally averaged DFS diurnal cycles corresponding to the $\mathrm{SO}_{2}$ profile retrievals.

Figure 7 shows the seasonal mean of diurnal cycle of DFS. The diurnal distribution in any season shows a single peak at midday due to the fact that the retrieval error at late evening or early morning overweights that at noon. If we compare the DFS around noon among the different seasons, values in summer are lower compared to the other seasons due to the lower $\mathrm{SO}_{2}$ amounts associated with larger uncertainties observed during this period.

\section{4 $\mathrm{SO}_{2}$ surface concentration retrieval verification}

For verification purposes, our retrieved $\mathrm{SO}_{2}$ surface concentrations have been compared to measurements from a modified commercial in situ instrument, based on pulsed UV fluorescence technology (Thermo Environmental Instruments Model 43C) (Li et al., 2007). Comparison results for December 2011 when the in situ instrument was freshly calibrated are shown in Fig. 8. Hourly and daily averages of $\mathrm{SO}_{2}$ concentration are plotted in Fig. 8a and b, respectively. A good agreement is obtained with a correlation coefficient of 0.86 and a slope of 0.95 .

In Fig. 9, the daytime variations of the MAX-DOAS and in situ $\mathrm{SO}_{2}$ surface concentration are compared for 9 continuous days. A very good agreement is found between both data sets, indicating the good overall reliability and the robustness of our MAX-DOAS retrievals.

\section{Results and discussion}

Based on the $\mathrm{SO}_{2}$ profiles retrieved for the period from March 2010 to February 2013, we have investigated the daily and seasonal variations of the $\mathrm{SO}_{2} \mathrm{VCD}$ and surface concentration and the possible influence of meteorological conditions, including atmospheric stability, wind direction and 

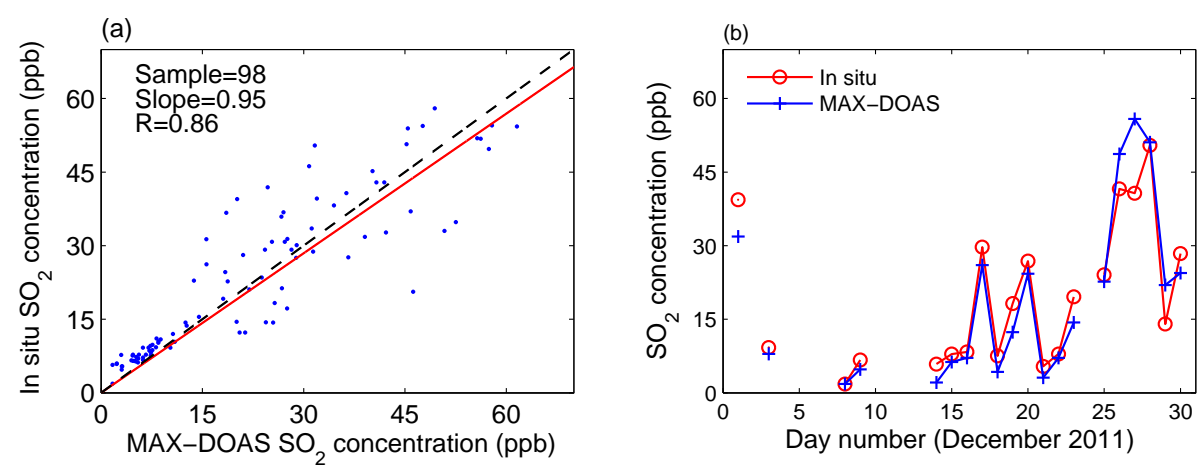

Figure 8. (a) Scatterplot of in situ $\mathrm{SO}_{2}$ surface concentrations (0-200 m layer) against MAX-DOAS data for December 2011 (hourly averaged concentrations). The red line denotes the linear least-squares fit to the data. (b) Temporal evolution of daily averaged MAX-DOAS and in situ $\mathrm{SO}_{2}$ concentrations during December 2011. Gaps in the data series are due to missing MAX-DOAS measurements.
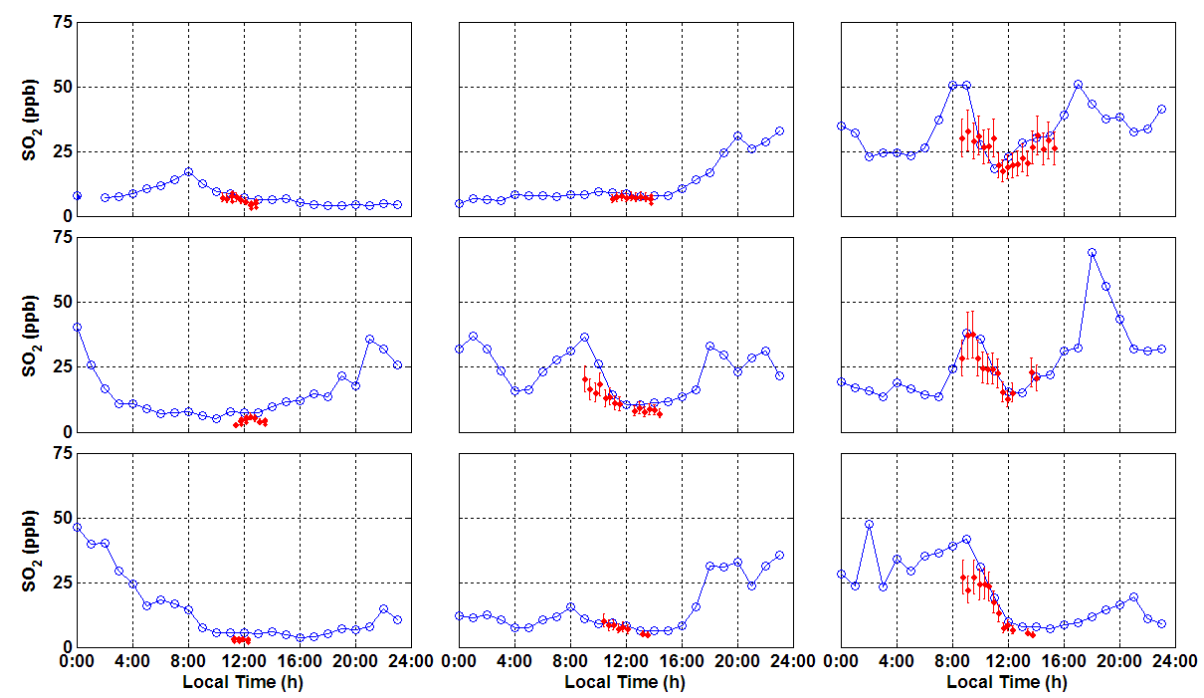

Figure 9. Comparison between in situ (blue, hourly means) and MAX-DOAS $\mathrm{SO}_{2}$ surface concentrations (red, each point represents the retrieval from one scan) for the 15-23 December 2011 period (upper plots are for 15-17 December, middle plots for 18-20 December, and lower plots for 21-23 December).

speed. We have adopted the following convention for the seasons: MAM, JJA, SON, and NJF for spring, summer, autumn, and winter, respectively.

\subsection{Seasonal variation of $\mathrm{SO}_{2}$}

Figure 10a shows that the $\mathrm{SO}_{2} \mathrm{VCD}$ is highly correlated with concentration close to the ground (correlation coefficient of 0.85). From Fig. 10b, we see that the temporal evolutions of $\mathrm{SO}_{2} \mathrm{VCD}$ and concentration are very similar, consistent with the fact that the $\mathrm{SO}_{2}$ emission sources are located near the ground.

The monthly averaged $\mathrm{SO}_{2} \mathrm{VCD}$ and surface concentrations are shown in Fig. 11. Both show a marked seasonal signature with a maximum in winter and a minimum in summer, implying that $\mathrm{SO}_{2}$ originates mainly from human sources rather than natural ones (Lin et al., 2011). Generally, the fluc- tuations of any atmospheric pollutant in a region of interest can be mainly attributed to three factors: emission level, residence time, and atmospheric transport (Wang et al., 2010; Lin et al., 2011). From the perspective of emission level, firstly, owing to enhanced domestic heating and associated coal and oil consumption in winter, the heating-related emissions of $\mathrm{SO}_{2}$ are much larger during this period than in summer. Secondly, the residence time, defined as the rate of removal mechanisms, also plays an important role in determining the seasonal variation of $\mathrm{SO}_{2}$ concentrations (Lee et al., 2011). Processes responsible for the removal of $\mathrm{SO}_{2}$ involve dry and wet deposition and homogeneous or inhomogeneous gas-phase reactions leading to the production of $\mathrm{H}_{2} \mathrm{SO}_{4}$ or sulfate (Tu et al., 2004). As shown in Fig. 12, the relative humidity is lower in winter, so that the removal of $\mathrm{SO}_{2}$ through wet deposition is not as substantial as in summer. Thirdly, the transport can also influence the evolution of $\mathrm{SO}_{2}$ at a given 

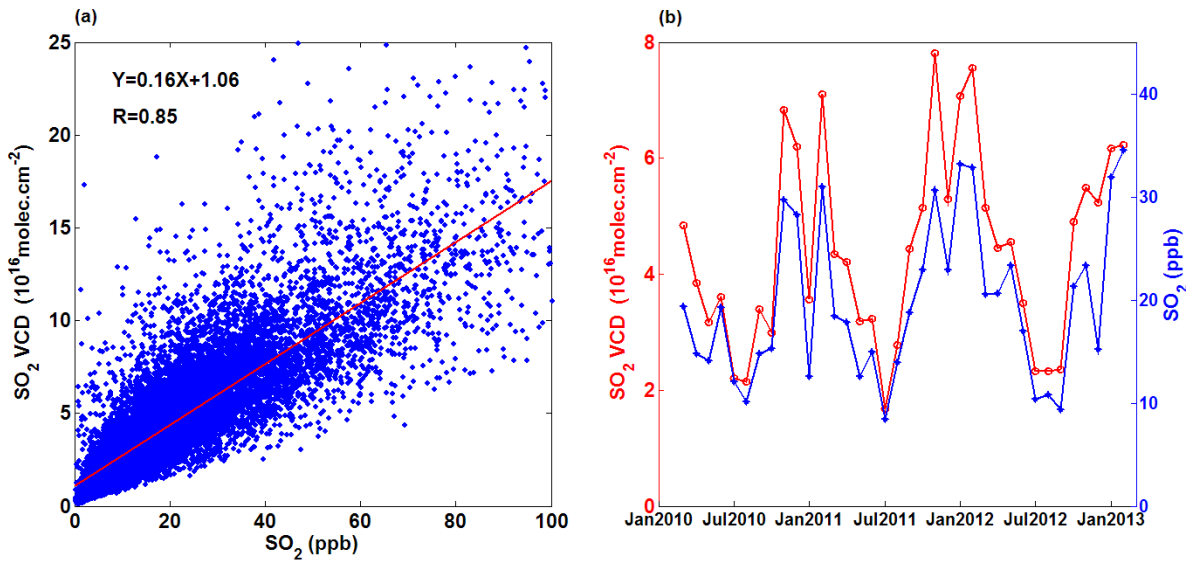

Figure 10. (a) Scatterplot of $\mathrm{SO}_{2} \mathrm{VCD}$ against surface concentration. The red line represents the linear least-squares fit to the data. (b) Temporal evolutions of monthly mean VCD and concentration from March 2010 to February 2013.
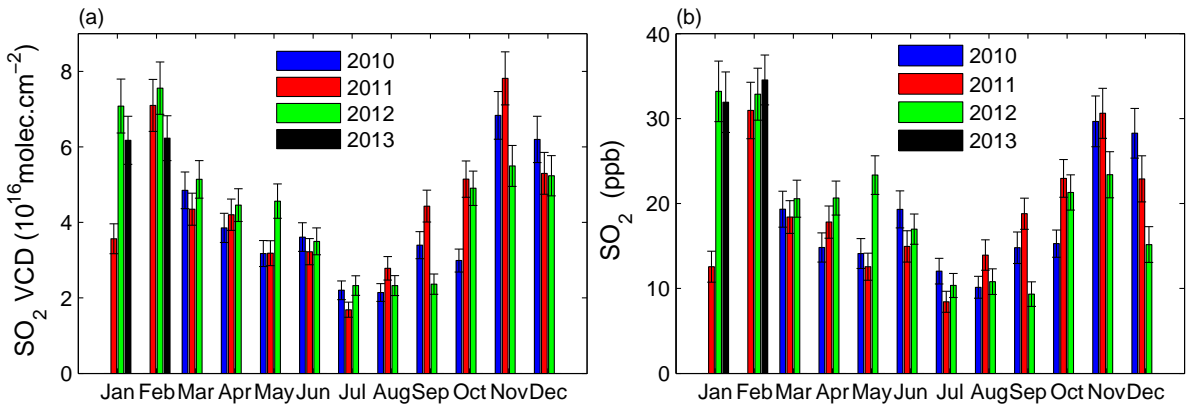

Figure 11. Monthly mean $\mathrm{SO}_{2}$ VCD (a) and surface concentration (b) for the March 2010-February 2013 period.

location. Although in winter the wind is stronger at Xianghe, the emissions also increase during the same period. In addition, the reduced atmospheric boundary layer height and frequent temperature inversion events result in larger surface concentrations due to an accumulation of $\mathrm{SO}_{2}$ in the lower troposphere (Meng et al., 2009). In summary, the aforementioned three factors jointly lead to the observed seasonal pattern of $\mathrm{SO}_{2}$ concentration in Xianghe.

From Fig. 11, we see that the amount of $\mathrm{SO}_{2}$ strongly increases in November with respect to October, as a consequence of increasing domestic heating (November is the beginning of the domestic heating season). Moreover, the higher wind speed observed in December (see Fig. 12) leads to a decrease of $\mathrm{SO}_{2}$ during this month due to more efficient diffusion and dilution effects. Finally, it is also noticeable that $\mathrm{SO}_{2}$ in January 2011 is remarkably lower than that in other years. This will be further discussed below.

\subsection{Impact of meteorological conditions}

Because of the high correlation coefficient and similar seasonal variations of the $\mathrm{SO}_{2} \mathrm{VCD}$ and concentration, we decided to investigate the impact of meteorological conditions on VCDs only. The variation of the $\mathrm{SO}_{2} \mathrm{VCD}$ is closely linked not only to the spatial distribution of emission sources but also to meteorological conditions including wind (speed and direction) and precipitation. As shown in Fig. 12, in general, the variations of temperature and humidity appear to exhibit similar behavior from year to year. This suggests that the contribution of the wind speed and direction as drivers of the $\mathrm{SO}_{2} \mathrm{VCD}$ variation is probably different over the different years investigated here. We further explore the relationship between $\mathrm{SO}_{2}$ and wind (speed and direction), as displayed in Fig. 13. It can be seen that the amount of $\mathrm{SO}_{2}$ is strongly dependent on the wind direction (Fig. 13a): high VCDs are prominent when the winds blow from the east, because Tangshan, a heavy industrial city releasing large amounts of $\mathrm{SO}_{2}$, is situated to the east of $\mathrm{Xi}$ anghe (see Fig. 1); in contrast, the northwest direction corresponds to a minimum in $\mathrm{SO}_{2} \mathrm{VCD}$, since it is a mountain area, characterized by much fewer emissions than in Xianghe. The wind therefore contributes significantly to the dispersion of the pollutants, as expected. Regarding the dependence of the $\mathrm{SO}_{2} \mathrm{VCD}$ on wind speed, Fig. 13b shows that the VCD is almost constant with wind speed for the $\mathrm{E}$ and SW, which means that no good dispersion happens with the wind from these directions, since high-emission industrial areas and Tangshan are located to the southwest and 


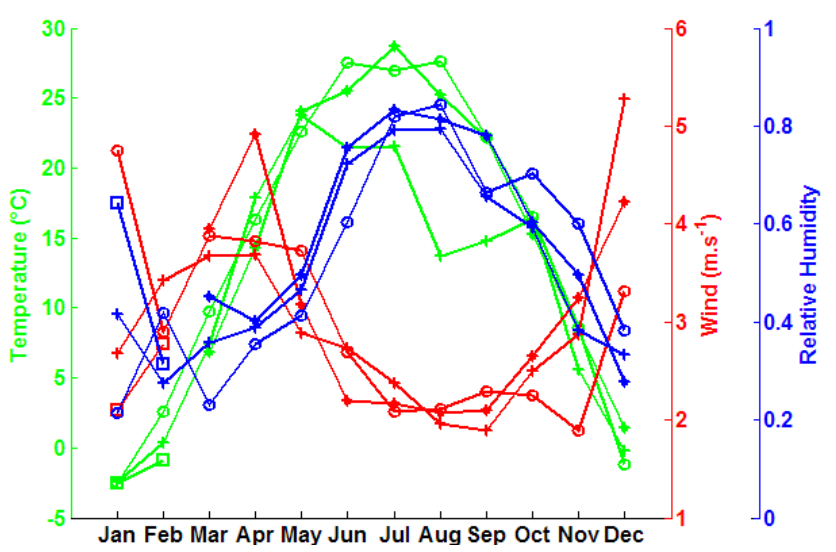

Figure 12. Seasonal cycles (monthly means) of temperature, humidity, and wind speed in 2010 (marker: star), 2011 (plus), 2012 (circle), and 2013 (square).

east of Xianghe, respectively. In contrast, an anticorrelation is observed for NE/NNE, NW, and SE, which means that the wind from these directions corresponding to less polluted areas can efficiently disperse pollutants. In addition, the $\mathrm{SO}_{2}$ content at Xianghe is more sensitive to the emission sources in Tangshan (E) than in Beijing (WNW), which is consistent with the fact that Beijing has taken regulatory actions to reduce air pollution through traffic-control measures and the closure of heavy polluting industries initiated before the 2008 Olympic Games (Yu et al., 2010).

The annual cycles of $\mathrm{SO}_{2}$ are generally in good agreement among the different years. However, the $\mathrm{SO}_{2} \mathrm{VCD}$ in January 2011 drastically deviates by up to $30 \%$ from the values during the same month in 2012 and 2013, which is also the case in May 2012. Wind roses in Fig. 14 reveal that the inter-annual variability of wind speed and direction is responsible for the significantly different $\mathrm{SO}_{2} \mathrm{VCD}$ in January 2011. During that month, the frequency of northwest winds reaches $70 \%$ and wind speed predominantly exceeds $5 \mathrm{~m} \mathrm{~s}^{-1}$. As mentioned above, the strong northwesterly wind favors the atmospheric dispersion of pollutants. Consequently, the $\mathrm{SO}_{2} \mathrm{VCDs}$ are generally lower than $4 \times 10^{16} \mathrm{molec} \mathrm{cm}^{-2}$. For January 2012 and 2013, uniformly distributed wind on each side and low velocity $\left(<5 \mathrm{~m} \mathrm{~s}^{-1}\right.$, frequency $>50 \%$ ) jointly result in relatively high $\mathrm{SO}_{2} \mathrm{VCDs}$ compared to January 2011. Similar features can explain the May 2012 case.

\subsection{Diurnal cycle}

In Fig. 15, we further compare the diurnal cycles of $\mathrm{SO}_{2}$ VCDs for the different seasons. Since the sunshine duration is different in the four seasons, the available time period for MAX-DOAS observations also differs: 07:30-17:30 in spring and autumn, 06:30-18:30 in summer, and 08:3016:30 in winter. As can be seen, the diurnal cycles for all years are very consistent, especially in summer. The retrieved
$\mathrm{SO}_{2}$ VCDs in autumn 2011 and spring 2012 are significantly higher than those during the same period of the other years due to the anomalous VCD values in November 2011 and May 2012. Furthermore, the amplitude of the $\mathrm{SO}_{2} \mathrm{VCD}$ diurnal cycle, which shows a minimum at noon and a maximum in the morning and late afternoon, is larger in winter. This can be explained by a strengthened diurnal variation of emission sources during this period (Meng et al., 2009).

It should be noted that similar investigations have been done for $\mathrm{NO}_{2}$ (Wang et al., 2014). One can conclude that both $\mathrm{NO}_{2}$ and $\mathrm{SO}_{2}$ display a similar seasonal variation and are impacted in the same way by meteorological conditions. However, $\mathrm{SO}_{2}$ abundances are always higher than $\mathrm{NO}_{2}$ ones and their diurnal cycles are different, especially in winter and summer: $\mathrm{SO}_{2}$ has a more pronounced diurnal cycle than $\mathrm{NO}_{2}$ in winter which is in line with the known diurnal cycle of burning of fossil fuels for heating and atmospheric stability, and the photochemical reaction activity leads to an obvious decrease of $\mathrm{NO}_{2}$ during daytime in summer (Wang et al., 2008; Meng et al., 2009; Lin et al., 2011).

\subsection{Relationship between $\mathrm{SO}_{2}$ and aerosols}

$\mathrm{SO}_{2}$ is known as a major aerosol precursor in the Beijing area through its conversion into sulfates and sulfuric acid by reaction with $\mathrm{OH}$ (see, e.g., Ma et al., 2012; Zhang et al., 2013). Since aerosol extinction profiles are retrieved in the first step of the $\mathrm{SO}_{2}$ retrieval (see Sect. 2.3), our data set offers a unique opportunity to investigate the relationship between $\mathrm{SO}_{2}$ emission and aerosol production in suburban Beijing. This will be done through a correlation study as in $\mathrm{Lu}$ et al. (2010) and Veefkind et al. (2011).

Figure 16 shows monthly scatterplots of the $\mathrm{SO}_{2}$ concentration versus aerosol extinction coefficient retrieved in the 0-200 m layer for the March 2010-February 2013 period. In all plots, data points correspond to MAX-DOAS scans satisfying the selection criteria based on the quality of the retrievals (see Sect. 2.3). A strong correlation (Pearson correlation coefficients in the 0.6-0.9 range) is obtained in JanuaryMarch and October-December while a significantly lower correlation is observed in late spring/summer with correlation coefficients around 0.3 in June-August. Similar features are found from the scatterplots of $\mathrm{SO}_{2} \mathrm{VCD}$ versus AOD but also when outliers outside the $95 \%$ confidence interval are removed and/or the uncertainties on both $\mathrm{SO}_{2}$ and aerosol data are taken into account (not shown here). The marked seasonality of the correlation between $\mathrm{SO}_{2}$ and aerosols is further illustrated in Fig. 17 where monthly correlation coefficients for both surface concentration and integrated column are reported. The positive correlation $(>0.2)$ observed throughout the year indicates that, in most cases, high pollution events in Xianghe are associated with enhanced $\mathrm{SO}_{2}$ and aerosol levels (Chan and Yao, 2008; Li et al., 2007). The higher correlation coefficients obtained in winter $(>0.6)$ suggest that anthropogenic $\mathrm{SO}_{2}$, through the formation of sulfate 

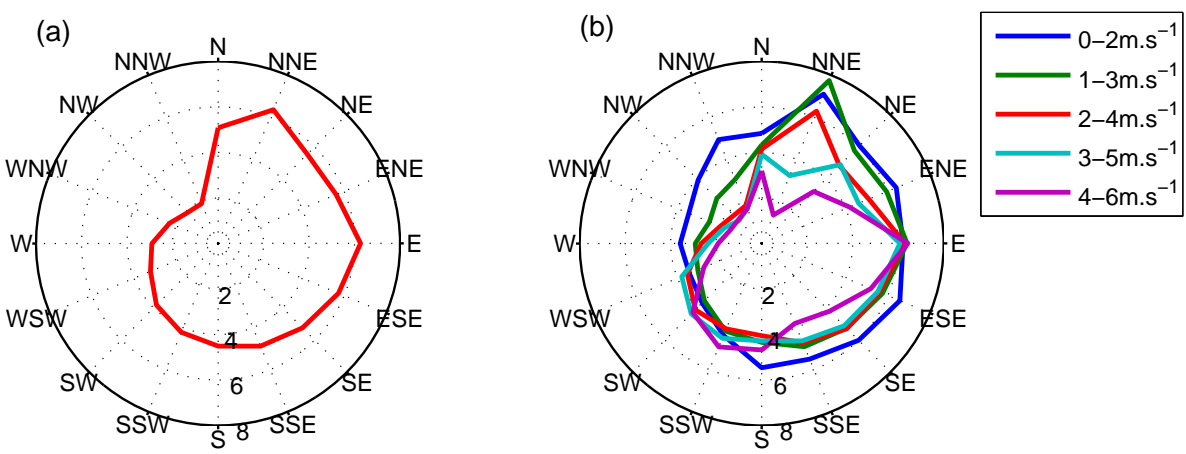

Figure 13. (a) Wind rose showing the $\mathrm{SO}_{2} \mathrm{VCD}\left(10^{16} \mathrm{molec} \mathrm{cm}^{-2}\right)$ as a function of the wind direction (average for all wind speed). (b) Dependence of $\mathrm{SO}_{2} \mathrm{VCD}\left(10^{16} \mathrm{molec}^{-2}\right)$ on wind direction for different wind speeds.
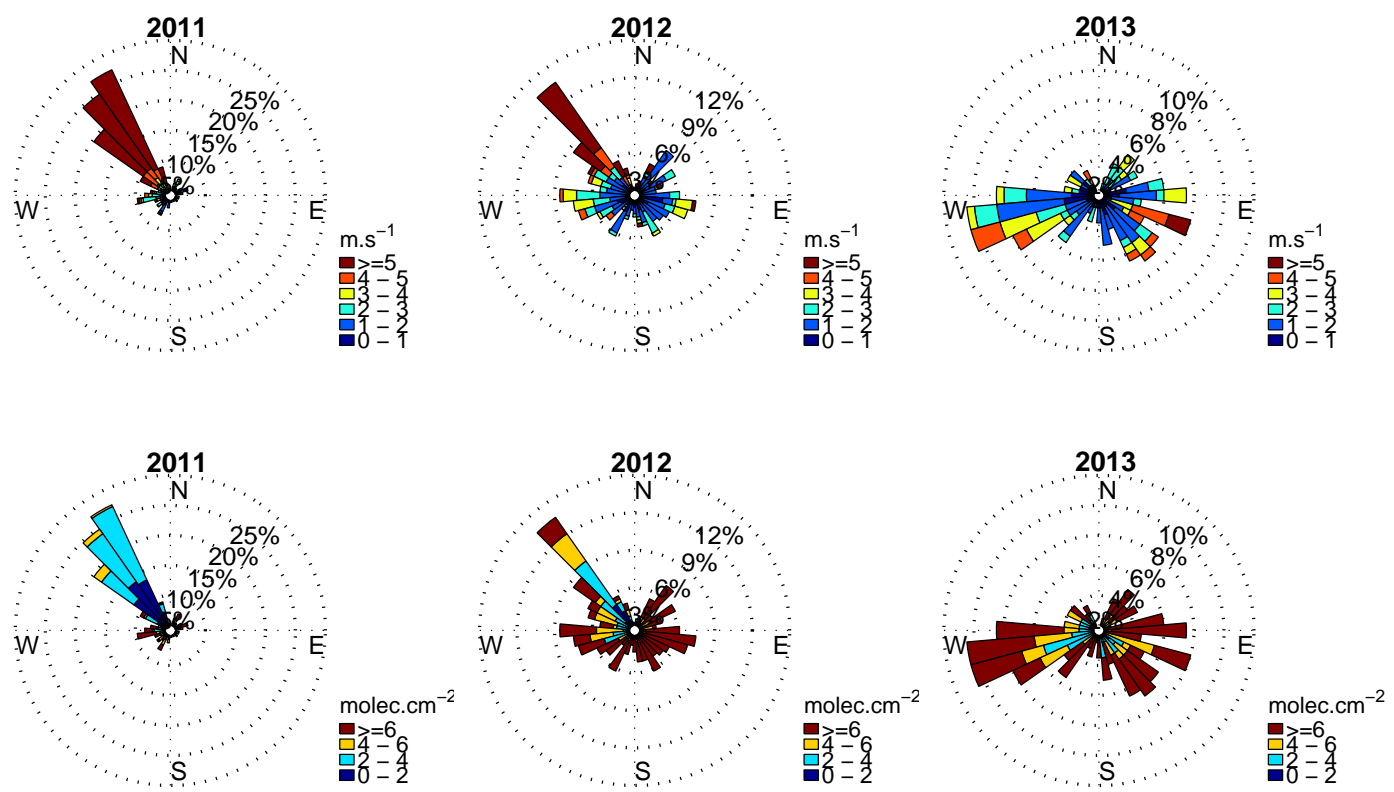

Figure 14. Wind rose for wind speed (first row; $\mathrm{m} \mathrm{s}^{-1}$ ) and $\mathrm{SO}_{2} \mathrm{VCD}$ (second row; $10^{16} \mathrm{molec} \mathrm{cm}^{-2}$ ) for January 2011 (first column), 2012 (second column), and 2013 (third column).

aerosols, is a major contributor to the total aerosol content during this period of the year. In late spring/summer, the Beijing area is strongly influenced by other sources of aerosols, especially particles emitted from massive agricultural fires in the surrounding region (Xia et al., 2013) as well as dust particles transported from the Kumutage and Taklimakan deserts in western China and from the Mongolian deserts (Yu et al., 2009). These perturbations by other aerosol sources combined with lower $\mathrm{SO}_{2}$ emissions, shorter lifetime of $\mathrm{SO}_{2}$ due to a more efficient oxidation, and different meteorological conditions could likely explain the significantly weaker correlation between anthropogenic $\mathrm{SO}_{2}$ and aerosols obtained in June-August. The intercept values much larger than zero found in summer scatterplots (see Fig. 16) further support the fact that aerosol sources other than anthropogenic ones play a significant role in summer, as also suggested by $\mathrm{Lu}$ et al. (2010) from a correlation study between $\mathrm{SO}_{2}$ emission inventories and AODs measured by the MODIS satellite instrument. It is however important to note that co-located measurements of the chemical composition of aerosols in Xianghe as well as additional investigations on the type and photochemical age of the air masses probed by the MAXDOAS instrument would be needed to confirm our findings.

\section{Summary and conclusions}

Tropospheric $\mathrm{SO}_{2}$ vertical profiles and corresponding column densities at the Xianghe station have been retrieved by applying an OEM-based profiling tool to continuous groundbased MAX-DOAS observations from March 2010 to February 2013. The $305-317.5 \mathrm{~nm}$ wavelength range was found to be the most suitable fitting window for near-noon DOAS 

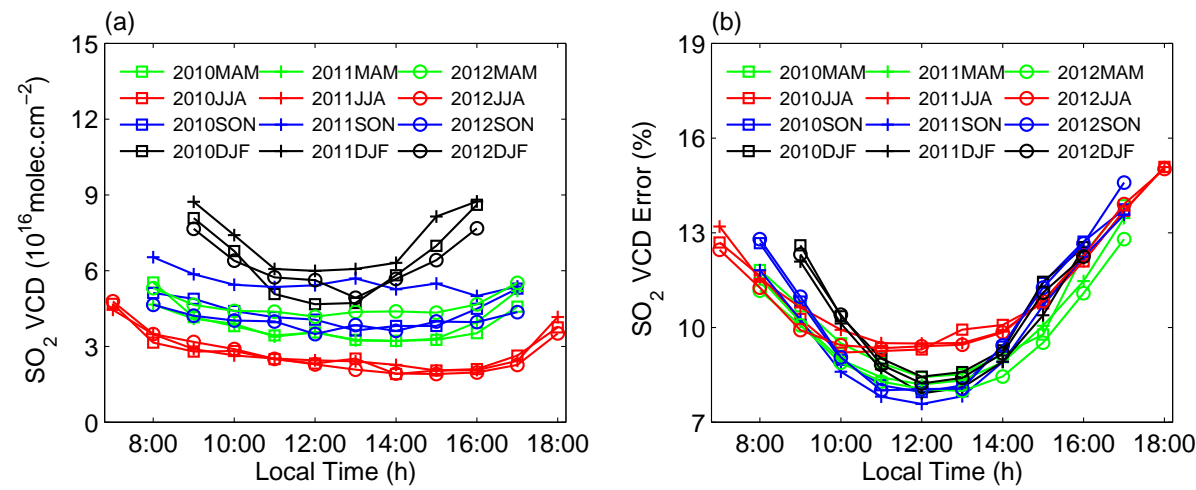

Figure 15. (a) Seasonally averaged $\mathrm{SO}_{2} \mathrm{VCD}$ diurnal cycles and (b) corresponding errors. Data points represent hourly means.
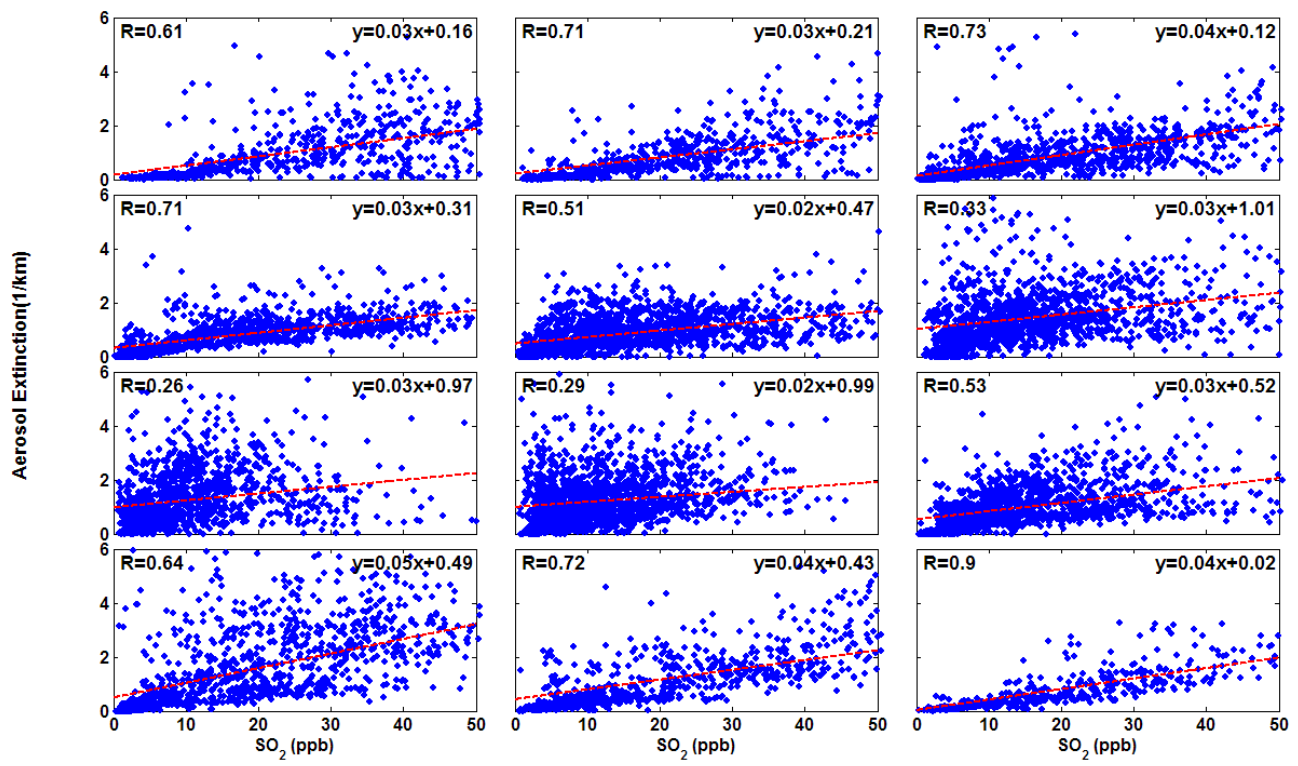

Figure 16. Scatterplots of aerosol extinction coefficient versus $\mathrm{SO}_{2}$ concentration in the 0-200m layer for months 1-12 of the March 2010-February 2013 period (first row from left to right is for January-March, respectively; second row for April-June; third row for JulySeptember; fourth row for October-December). The data points correspond to the different MAX-DOAS scans. The red line denotes the linear least-squares fit to the data.

analysis of $\mathrm{SO}_{2}$. For verification purpose, retrieved $\mathrm{SO}_{2}$ surface concentrations have been compared to collocated in situ data. An excellent agreement was found, with correlation coefficient and slope close to 0.9 , indicating the good reliability and robustness of our retrievals.

These MAX-DOAS measurements have been used to investigate the seasonal and diurnal cycles of $\mathrm{SO}_{2}$ vertical columns and surface concentrations, in combination with conventional meteorological data (temperature, humidity, and wind speed and direction). Regarding the seasonal variation, both VCD and surface concentrations exhibit the same patterns, with a maximum in winter (February) and a minimum in summer (July), in accordance with the large emissions due to domestic heating in winter. The high levels of $\mathrm{SO}_{2}$ during the cold season are further enhanced by the weakness of the wet deposition mechanism and, in case of surface concentration, by the frequent temperature-inversion events occurring during this period, favoring the accumulation of $\mathrm{SO}_{2}$ in the atmospheric layers close to the ground. The variation of the $\mathrm{SO}_{2}$ amount in Xianghe is also found to be largely driven by wind speed and direction. In the case of east or southwest wind, the VCD at the station remains almost constant with the increase of wind speed, since the city of Tangshan and heavy polluting industries are located to the east and southwest of Xianghe, respectively. In contrast, an anticorrelation between $\mathrm{SO}_{2} \mathrm{VCD}$ and wind speed is observed for NE/NNE, NW, and SE directions, which means the wind from these directions can efficiently disperse the pollution in Xianghe. With respect to the diurnal cycle, larger $\mathrm{SO}_{2}$ amounts are obtained in the early morning 


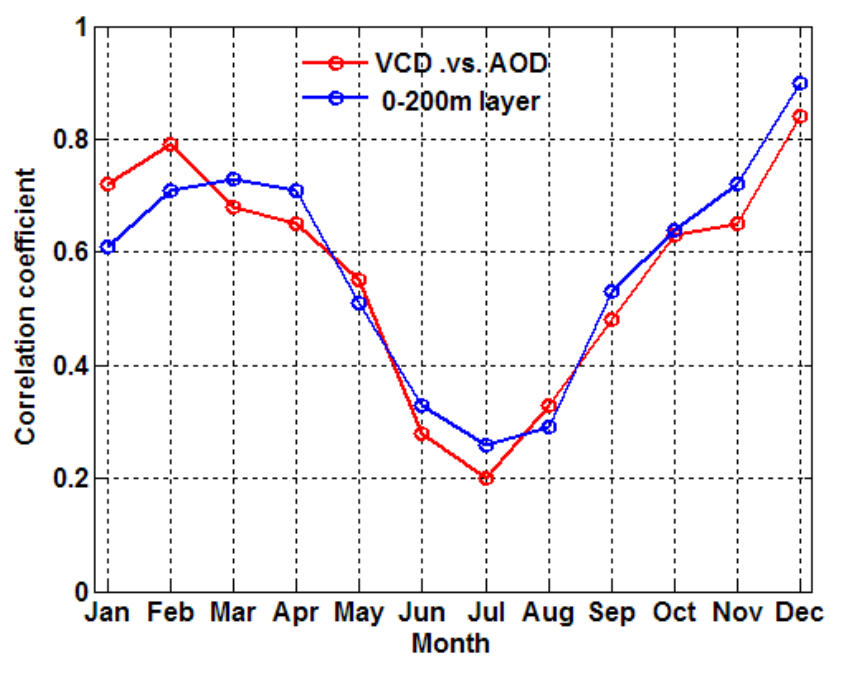

Figure 17. Seasonal variation of the correlation coefficient between $\mathrm{SO}_{2}$ and aerosols over the March 2010-February 2013 period. The red curve corresponds to VCD versus AOD and the blue curve to $\mathrm{SO}_{2}$ concentration versus aerosol extinction coefficient in the 0 $200 \mathrm{~m}$ layer.

and late evening with a minimum around noon, in line with the diurnal variation of pollutant emission and atmospheric state. Moreover, the diurnal cycle is more pronounced during wintertime, mainly due to the more marked diurnal variation of emission sources during this season. The relationship between $\mathrm{SO}_{2}$ and aerosols has been also investigated. A strong correlation between both is found in winter but not in summer. This seasonality could be related to the fact that, in the Beijing area in winter, the aerosol content depends significantly on anthropogenic $\mathrm{SO}_{2}$ through the formation of sulfate aerosols while, in spring/summer, dust and biomass burning particles, which are much less $\mathrm{SO}_{2}$-dependent, are also important aerosol sources. It is however worth noting that such kind of correlation analysis should be combined to aerosol composition measurements in order to definitely conclude whether the conversion of $\mathrm{SO}_{2}$ to sulfate is a dominant aerosol source or not.

These 3-year MAX-DOAS SO $\mathrm{S}_{2}$ measurements in Xianghe constitute a unique data set for validating and improving spaceborne observations over China, which is the region in the world where anthropogenic $\mathrm{SO}_{2}$ emissions are the largest (Yang et al., 2013; Boynard et al., 2014). In particular, retrieved $\mathrm{SO}_{2}$ vertical profiles can be used as a priori information for the AMF calculation in satellite retrievals. Moreover, the combination of both integrated columns and surface concentrations could provide useful information to make explicitly the link between measured satellite columns and surface concentrations.
Acknowledgements. This work was supported by China Scholarship Council, the Special Scientific Research Fund of Meteorological Public Welfare Profession of China (grant no. GYHY201106045-52), and the National Natural Science Foundation of China (grant no. 41175030). We acknowledge the Belgian Federal Science Policy Office, Brussels (AGACC-II project), and the funding obtained from the EU 7th Framework Programme project NORS (contract 284421) and the ESA CEOS Intercalibration project (ESA/ESRIN contract 22202/09/I-EC). We would like also to thank J. Z. Ma (Chinese Academy of Meteorological Sciences, Beijing; Editor of this paper) and two anonymous referees for their helpful comments.

Edited by: J. Ma

\section{References}

Bobrowski, N. and Platt, U.: $\mathrm{SO}_{2} / \mathrm{BrO}$ ratios studied in five volcanic plumes, J. Volcanol. Geotherm. Res., 166, 147-160, 2007.

Bobrowski, N., von Glasow, R., Aiuppa, A., Inguaggiato, S., Louban, I., Ibrahim, O. W., and Platt, U.: Reactive halogen chemistry in volcanic plumes, J. Geophys. Res., 112, D06311, doi:10.1029/2006JD007206, 2007.

Bogumil, K., Orphal, J., Homann, T., Voigt, S., Spietz, P., Fleischmann, O. C., Vogel, A., Hartmann, M., Bovensmann, H., Frerik, J., and Burrows, J. P.: Measurements of molecular absorption spectra with the SCIAMACHY Pre-Flight Model: Instrument characterization and reference spectra for atmospheric remote sensing in the $230-2380 \mathrm{~nm}$ region, J. Photoch. Photobio. A, 157, 167-184, 2003.

Boynard, A., Clerbaux, C., Clarisse, L., Safieddine, S., Pommier, M., Van Damme, M., Bauduin, S., Oudot, C., Hadji-Lazaro, J., Hurtmans, D., and Coheur, P.-F.: First simultaneous space measurements of atmospheric pollutants in the boundary layer from IASI: a case study in the North China Plain, Geophys. Res. Lett., 41, 645-651, doi:10.1002/2013GL058333, 2014.

Brinksma, E. J., Pinardi, G., Volten, H., Braak, R., Richter, A., Schonhardt, A., van Roozendael, M., Fayt, C., Hermans, C., Dirksen, R. J., Vlemmix, T., Berkhout, A. J. C., Swart, D. P. J., Oetjen, H., Wittrock, F., Wagner, T., Ibrahim, O. W., de Leeuw, G., Moerman, M., Curier, R. L., Celarier, E. A., Cede, A., Knap, W. H., Veefkind, J. P., Eskes, H. J., Allaart, M., Rothe, R., Piters, A. J. M., and Levelt, P. F.: The 2005 and 2006 DANDELIONS $\mathrm{NO}_{2}$ and aerosol intercomparison campaigns, J. Geophys. Res., 113, D16S46, doi:10.1029/2007jd008808, 2008.

Cachorro, V. E., Durán, P., Vergaz, R., and de Frutos, A. M.: Measurements of the atmospheric turbidity of the north-centre continental area in Spain: Spectral aerosol optical depth and Ångström turbidity parameters, J. Aerosol Sci., 31, 687-702, 2000.

Chan, C. K. and Yao, X.: Air pollution in mega cities in China, Atmos. Environ., 42, 1-42, 2008.

Chance, K. V. and Spurr, R. J.: Ring effect studies: Rayleigh scattering, including molecular parameters for rotational Raman scattering, and the Fraunhofer spectrum, Appl. Optics, 36, 52245230, 1997.

Clémer, K., Van Roozendael, M., Fayt, C., Hendrick, F., Hermans, C., Pinardi, G., Spurr, R., Wang, P., and De Mazière, M.: Multiple wavelength retrieval of tropospheric aerosol optical proper- 
ties from MAXDOAS measurements in Beijing, Atmos. Meas. Tech., 3, 863-878, doi:10.5194/amt-3-863-2010, 2010.

Eisinger, M. and Burrows, J. P.: Tropospheric sulfur dioxide observed by the ERS-2/GOME instrument, Geophys. Res. Lett., 25, 4177-4180, doi:10.1029/1998GL900128, 1998.

Fioletov, V. E., McLinden, C. A., Krotkov, N., Yang, K., Loyola, D. G., Valks, P., Theys, N., Van Roozendael, M., Nowlan, C. R., Chance, K., Liu, X., Lee, C., and Martin, R. V.: Application of OMI, SCIAMACHY, and GOME-2 satellite $\mathrm{SO}_{2}$ retrievals for detection of large emission sources, J. Geophys. Res.-Atmos., 118, 11399-11418, doi:10.1002/jgrd.50826, 2013.

Fleischmann, O. C., Hartmann, M., Burrows, J. P., and Orphal, J.: New ultraviolet absorption cross-sections of $\mathrm{BrO}$ at atmospheric temperatures measured by time-windowing Fourier transform spectroscopy, J. Photoch. Photobio. A: Chemistry, 168, 117-132, 2004.

Frieß, U., Monks, P. S., Remedios, J. J., Rozanov, A., Sinreich, R., Wagner, T., and Platt, U.: MAX-DOAS $\mathrm{O}_{4}$ measurements: A new technique to derive information on atmospheric aerosols: 2. Modeling studies, J. Geophys. Res., 111, D14203, doi:10.1029/2005jd006618, 2006.

Frieß, U., Sihler, H., Sander, R., Pöhler, D., Yilmaz, S., and Platt, U.: The vertical distribution of $\mathrm{BrO}$ and aerosols in the Arctic: Measurements by active and passive differential optical absorption spectroscopy, J. Geophys. Res., 116, D00R04, doi:10.1029/2011JD015938, 2011.

Frins, E., Osorio, M., Casaballe, N., Belsterli, G., Wagner, T., and Platt, U.: DOAS-measurement of the $\mathrm{NO}_{2}$ formation rate from $\mathrm{NO}_{\mathrm{x}}$ emissions into the atmosphere, Atmos. Meas. Tech., 5, 1165-1172, doi:10.5194/amt-5-1165-2012, 2012.

Galle, B., Johansson, M., Rivera, C., Zhang, Y., Kihlman, M., Kern, C., Lehmann, T., Platt, U., Arellano, S., and Hidalgo, S.: Network for Observation of Volcanic and Atmospheric Change (NOVAC)A global network for volcanic gas monitoring: Network layout and instrument description, J. Geophys. Res., 115, D05304, doi:10.1029/2009JD011823, 2010.

Gauderman, W. J., McConnell, R., Gilliland, F., London, S., Thomas, D., Avol, E., Vora, H., Berhane, K., Rappaport, E. B., and Lurmann, F.: Association between air pollution and lung function growth in southern California children, Am. J. Resp. Crit. Care., 162, 1383-1390, 2000.

Grainger, J. and Ring, J.: Anomalous Fraunhofer line profiles, Nature, 193, p. 762, 1962.

Großmann, K., Frieß, U., Peters, E., Wittrock, F., Lampel, J., Yilmaz, S., Tschritter, J., Sommariva, R., von Glasow, R., Quack, B., Krüger, K., Pfeilsticker, K., and Platt, U.: Iodine monoxide in the Western Pacific marine boundary layer, Atmos. Chem. Phys., 13, 3363-3378, doi:10.5194/acp-13-3363-2013, 2013.

Hönninger, G., von Friedeburg, C., and Platt, U.: Multi axis differential optical absorption spectroscopy (MAX-DOAS), Atmos. Chem. Phys., 4, 231-254, doi:10.5194/acp-4-231-2004, 2004.

Heckel, A., Richter, A., Tarsu, T., Wittrock, F., Hak, C., Pundt, I., Junkermann, W., and Burrows, J. P.: MAX-DOAS measurements of formaldehyde in the Po-Valley, Atmos. Chem. Phys., 5, 909918, doi:10.5194/acp-5-909-2005, 2005.

Hendrick, F., Barret, B., Van Roozendael, M., Boesch, H., Butz, A., De Mazière, M., Goutail, F., Hermans, C., Lambert, J.C., Pfeilsticker, K., and Pommereau, J.-P.: Retrieval of nitrogen dioxide stratospheric profiles from ground-based zenith- sky UV-visible observations: validation of the technique through correlative comparisons, Atmos. Chem. Phys., 4, 2091-2106, doi:10.5194/acp-4-2091-2004, 2004.

Hendrick, F., Müller, J.-F., Clémer, K., Wang, P., De Mazière, M., Fayt, C., Gielen, C., Hermans, C., Ma, J. Z., Pinardi, G., Stavrakou, T., Vlemmix, T., and Van Roozendael, M.: Four years of ground-based MAX-DOAS observations of HONO and $\mathrm{NO}_{2}$ in the Beijing area, Atmos. Chem. Phys., 14, 765-781, doi:10.5194/acp-14-765-2014, 2014.

Hermans, C., Vandaele, A., Fally, S., Carleer, M., Colin, R., Coquart, B., Jenouvrier, A., and Merienne, M.-F.: Absorption crosssection of the collision-induced bands of oxygen from the UV to the NIR, in: Weakly interacting molecular pairs: unconventional absorbers of radiation in the atmosphere, Springer, 193202, 2003.

Holben, B., Eck, T., Slutsker, I., Tanre, D., Buis, J., Setzer, A., Vermote, E., Reagan, J., Kaufman, Y., and Nakajima, T.: AERONET-A federated instrument network and data archive for aerosol characterization, Remote Sens. Environ., 66, 1-16, 1998.

Irie, H., Takashima, H., Kanaya, Y., Boersma, K. F., Gast, L., Wittrock, F., Brunner, D., Zhou, Y., and Van Roozendael, M.: Eightcomponent retrievals from ground-based MAX-DOAS observations, Atmos. Meas. Tech., 4, 1027-1044, doi:10.5194/amt-41027-2011, 2011.

Krotkov, N. A., Carn, S. A., Krueger, A. J., Bhartia, P. K., and Yang, K.: Band Residual Difference Algorithm for Retrieval of $\mathrm{SO}_{2}$ From the Aura Ozone Monitoring Instrument (OMI), IEEE, Trans. Geosci. Remote Sens., 44, 1259-1266, 2006.

Lee, C., Richter, A., Lee, H., Kim, Y. J., Burrows, J. P., Lee, Y. G., and Choi, B. C.: Impact of transport of sulfur dioxide from the Asian continent on the air quality over Korea during May 2005, Atmos. Environ., 42, 1461-1475, 2008.

Lee, C., Martin, R. V., van Donkelaar, A., O'Byrne, G., Krotkov, N., Richter, A., Huey, L. G., and Holloway, J. S.: Retrieval of vertical columns of sulfur dioxide from SCIAMACHY and OMI: Air mass factor algorithm development, validation, and error analysis, J. Geophys. Res., 114, D22303, doi:10.1029/2009JD012123, 2009.

Lee, C., Martin, R. V., van Donkelaar, A., Lee, H., Dickerson, R. R., Hains, J. C., Krotkov, N., Richter, A., Vinnikov, K., and Schwab, J. J.: $\mathrm{SO}_{2}$ emissions and lifetimes: Estimates from inverse modeling using in situ and global, space based(SCIAMACHY and OMI) observations, J. Geophys. Res., 116, D06304, doi:10.1029/2010JD014758, 2011.

Li, C., Marufu, L. T., Dickerson, R. R., Li, Z., Wen, T., Wang, Y., Wang, P., Chen, H., and Stehr, J. W.: In situ measurements of trace gases and aerosol optical properties at a rural site in northern China during East Asian Study of Tropospheric Aerosols: An International Regional Experiment 2005, J. Geophys. Res., 112, D22S04, doi:10.1029/2006JD007592, 2007.

Lin, W., Xu, X., Ge, B., and Liu, X.: Gaseous pollutants in Beijing urban area during the heating period 2007-2008: variability, sources, meteorological, and chemical impacts, Atmos. Chem. Phys., 11, 8157-8170, doi:10.5194/acp-11-8157-2011, 2011.

Lu, Z., Streets, D. G., Zhang, Q., Wang, S., Carmichael, G. R., Cheng, Y. F., Wei, C., Chin, M., Diehl, T., and Tan, Q.: Sulfur dioxide emissions in China and sulfur trends in East Asia since 2000, Atmos. Chem. Phys., 10, 6311-6331, doi:10.5194/acp-106311-2010, 2010. 
Ma, J. Z., Xu, X. B., Zhao, C. S., and Yan, P.: A review of atmospheric chemistry research in China: Photochemical smog, haze pollution, and gas-aerosol interactions, Adv. Atmos. Sci., 29, 1006-1026, 2012.

Ma, J. Z., Beirle, S., Jin, J. L., Shaiganfar, R., Yan, P., and Wagner, T.: Tropospheric $\mathrm{NO}_{2}$ vertical column densities over Beijing: results of the first three years of ground-based MAX-DOAS measurements (2008-2011) and satellite validation, Atmos. Chem. Phys., 13, 1547-1567, doi:10.5194/acp-13-1547-2013, 2013.

Meller, R. and Moortgat, G. K.: Temperature dependence of the absorption cross sections of formaldehyde between 223 and 323 $\mathrm{K}$ in the wavelength range $225-375 \mathrm{~nm}$, J. Geophys. Res., 105, 7089-7101, 2000.

Meng, X., Wang, P., Wang, G., Yu, H., and Zong, X.: Variation and transportation characteristics of $\mathrm{SO}_{2}$ in winter over Beijing and its surrounding areas, Climatic and Environmental Research (in Chinese), 14, 309-317, 2009.

Nowlan, C. R., Liu, X., Chance, K. V., Cai, Z., Kurosu, T. P., Lee, C., and Martin, R. V.: Retrievals of sulfur dioxide from the Global Ozone Monitoring Experiment 2 (GOME-2) using an optimal estimation approach: Algorithm and initial validation, J. Geophys. Res., 116, D18301, doi:10.1029/2011JD015808, 2011.

Platt, U. and Stutz, J.: Differential Optical Absorption Spectroscopy (DOAS): Principles and applications, ISBN 978-3-540-21193-8, Springer, Berlin-Heidelberg, 2008.

Puķīe, J., Kühl, S., Deutschmann, T., Platt, U., and Wagner, T.: Extending differential optical absorption spectroscopy for limb measurements in the UV, Atmos. Meas. Tech., 3, 631-653, doi:10.5194/amt-3-631-2010, 2010.

Rodgers, C. D.: Inverse methods for atmospheric sounding : theory and practice, World Scientific Publishing, Singapore-New Jersey-London-Hong Kong, 2000.

Roscoe, H. K., Van Roozendael, M., Fayt, C., du Piesanie, A., Abuhassan, N., Adams, C., Akrami, M., Cede, A., Chong, J., Clémer, K., Friess, U., Gil Ojeda, M., Goutail, F., Graves, R., Griesfeller, A., Grossmann, K., Hemerijckx, G., Hendrick, F., Herman, J., Hermans, C., Irie, H., Johnston, P. V., Kanaya, Y., Kreher, K., Leigh, R., Merlaud, A., Mount, G. H., Navarro, M., Oetjen, H., Pazmino, A., Perez-Camacho, M., Peters, E., Pinardi, G., Puentedura, O., Richter, A., Schönhardt, A., Shaiganfar, R., Spinei, E., Strong, K., Takashima, H., Vlemmix, T., Vrekoussis, M., Wagner, T., Wittrock, F., Yela, M., Yilmaz, S., Boersma, F., Hains, J., Kroon, M., Piters, A., and Kim, Y. J.: Intercomparison of slant column measurements of $\mathrm{NO}_{2}$ and $\mathrm{O}_{4}$ by MAX-DOAS and zenith-sky UV and visible spectrometers, Atmos. Meas. Tech., 3, 1629-1646, doi:10.5194/amt-3-1629-2010, 2010.

Tu, F. H., Thornton, D. C., Bandy, A. R., Carmichael, G. R., Tang, Y., Thornhill, K. L., Sachse, G. W., and Blake, D. R.: Long-range transport of sulfur dioxide in the central Pacific, J. Geophys. Res., 109, D15S08, doi:10.1029/2003JD004309, 2004.

Vandaele, A., Simon, P. C., Guilmot, J. M., Carleer, M., and Colin, R.: $\mathrm{SO}_{2}$ absorption cross section measurement in the UV using a Fourier transform spectrometer, J. Geophys. Res., 99, 2559925605, 1994.

Vandaele, A. C., Hermans, C., Simon, P. C., Carleer, M., Colin, R., Fally, S., Merienne, M.-F., Jenouvrier, A., and Coquart, B.: Measurements of the $\mathrm{NO}_{2}$ absorption cross-section from $42000 \mathrm{~cm}^{-1}$ to $10000 \mathrm{~cm}^{-1}(238-1000 \mathrm{~nm})$ at 220 and $294 \mathrm{~K}$, J. Quant. Spectrosc. Ra., 59, 171-184, 1998.
Van Roozendael, M., Loyola, D., Spurr, R., Balis, D., Lambert, J.-C., Livschitz, Y., Valks, P., Ruppert, T., Kenter, P., Fayt, C., and Zehner, C.: Ten years of GOME/ERS-2 total ozone data - The new GOME data processor (GDP) version 4: 1. Algorithm description, J. Geophys. Res., 111, D14311, doi:10.1029/2005JD006375, 2006.

Veefkind, J. P., Boersma, K. F., Wang, J., Kurosu, T. P., Krotkov, N., Chance, K., and Levelt, P. F.: Global satellite analysis of the relation between aerosols and short-lived trace gases, Atmos. Chem. Phys., 11, 1255-1267, doi:10.5194/acp-11-1255-2011, 2011.

Vlemmix, T., Piters, A. J. M., Stammes, P., Wang, P., and Levelt, P. F.: Retrieval of tropospheric $\mathrm{NO}_{2}$ using the MAX-DOAS method combined with relative intensity measurements for aerosol correction, Atmos. Meas. Tech., 3, 1287-1305, doi:10.5194/amt-31287-2010, 2010.

Wagner, T., Dix, B., von Friedeburg, C., Friess, U., Sanghavi, S., Sinreich, R., and Platt, U.: MAX-DOAS $\mathrm{O}_{4}$ measurements: A new technique to derive information on atmospheric aerosols - Principles and information content, J. Geophys. Res., 109, D22205, doi:10.1029/2004jd004904, 2004.

Wagner, T., Beirle, S., Brauers, T., Deutschmann, T., Frieß, U., Hak, C., Halla, J. D., Heue, K. P., Junkermann, W., Li, X., Platt, U., and Pundt-Gruber, I.: Inversion of tropospheric profiles of aerosol extinction and $\mathrm{HCHO}$ and $\mathrm{NO}_{2}$ mixing ratios from MAX-DOAS observations in Milano during the summer of 2003 and comparison with independent data sets, Atmos. Meas. Tech., 4, 2685-2715, doi:10.5194/amt-4-2685-2011, 2011.

Wang, T., Nie, W., Gao, J., Xue, L. K., Gao, X. M., Wang, X. F., Qiu, J., Poon, C. N., Meinardi, S., Blake, D., Wang, S. L., Ding, A. J., Chai, F. H., Zhang, Q. Z., and Wang, W. X.: Air quality during the 2008 Beijing Olympics: secondary pollutants and regional impact, Atmos. Chem. Phys., 10, 7603-7615, doi:10.5194/acp10-7603-2010, 2010.

Wang, T., Wang, P., Yu, H., Zhang, X., Zhou, B., Si, F., Wang, S., Bai, W., Zhou, H., and Zhao, H.: Intercomparison of slant column measurements of $\mathrm{NO}_{2}$ by ground-based MAX-DOAS, Acta Phys. Sin., 62, 054206, doi:10.7498/aps.62.054206, 2013.

Wang, T., Wang, P., Yu, H., and Sun, L.: Analysis of the characteristics of tropospheric $\mathrm{NO}_{2}$ in Xianghe based on MAX-DOAS measurement, Climatic and Environmental Research (in Chinese), 19, 51-60, 2014.

Wang, W., Chai, F., Zhang, K., Wang, S., Chen, Y., Wang, X., and Yang,Y.: Study on ambient air quality in Beijing for the summer 2008 Olympic Games, Air Qual, Atmos. Health, 1, 31-36, 2008.

Wittrock, F., Oetjen, H., Richter, A., Fietkau, S., Medeke, T., Rozanov, A., and Burrows, J. P.: MAX-DOAS measurements of atmospheric trace gases in Ny-Ålesund - Radiative transfer studies and their application, Atmos. Chem. Phys., 4, 955-966, doi:10.5194/acp-4-955-2004, 2004.

Wu, F. C., Xie, P. H., Li, A., Chan, K. L., Hartl, A., Wang, Y., Si, F. Q., Zeng, Y., Qin, M., Xu, J., Liu, J. G., Liu, W. Q., and Wenig, M.: Observations of $\mathrm{SO}_{2} 2$ by mobile DOAS in the Guangzhou eastern area during the Asian Games 2010, Atmos. Meas. Tech., 6, 2277-2292, doi:10.5194/amt-6-2277-2013, 2013.

Xia, X., Zong, X., and Sun, L.: Exceptionally active agricultural fire season in mid-eastern China in June 2012 and its impact on atmospheric environment, J. Geophys. Res. Atmos., 118, 98899900, doi:10.1002/jgrd.50770, 2013. 
Yan, P., Huang, J., and Draxler, R.: The long-term simulation of surface $\mathrm{SO}_{2}$ and evaluation of contributions from the different emission sources to Beijing city, Science in China Series D (Earth Sciences), 48, 196-208, 2005.

Yan, P., Wang, X., Wang, Z., and Wu, Q.: Analysis of decreases in $\mathrm{NO}_{2}$ concentrations during Beijing Olympic Games in 2008, Climatic and Environmental Research, 15, 609-615, 2010 (in Chinese).

Yang, K., Dickerson, R. R., Carn, S. A., Ge, C., and Wang, J.: First observations of $\mathrm{SO}_{2}$ from satellite Suomi NPP OMPS: Widespread air pollution events over China, Geophys. Res. Lett., 40, 4957-4962, doi:10.1002/grl.50952, 2013.

Yu, H., Wang, P., Zong, X., Li, X., and Lü, D.: Change of $\mathrm{NO}_{2}$ column density over Beijing from satellite measurement during the Beijing 2008 Olympic Games, Chinese Sci. Bull., 55, 308$313,2010$.
Yu, X., Zhu, B., and Zhang, M.: Seasonal variability of aerosol optical properties over Beijing, Atmos. Environ., 43, 4095-4101, 2009.

Zhang, R., Jing, J., Tao, J., Hsu, S.-C., Wang, G., Cao, J., Lee, C. S. L., Zhu, L., Chen, Z., Zhao, Y., and Shen, Z.: Chemical characterization and source apportionment of $\mathrm{PM}_{2.5}$ in Beijing: seasonal perspective, Atmos. Chem. Phys., 13, 7053-7074, doi:10.5194/acp-13-7053-2013, 2013.

Zhao, B., Wang, P., Ma, J. Z., Zhu, S., Pozzer, A., and Li, W.: A high-resolution emission inventory of primary pollutants for the Huabei region, China, Atmos. Chem. Phys., 12, 481-501, doi:10.5194/acp-12-481-2012, 2012. 